\title{
Algal Biofuels: Current Status and Key Challenges
}

\author{
Marwa G. Saad ${ }^{1,2,+}{ }^{\text {, Noura S. Dosoky }}{ }^{3, *,+}+{ }^{-}$, Mohamed S. Zoromba ${ }^{4,5}$ and Hesham M. Shafik ${ }^{1}$ \\ 1 Department of Biology, Faculty of Science, Port-Said University, Port-Said 42521, Egypt; \\ marwa.aly@sci.psu.edu.eg (M.G.S.); hesham_shafik@sce.psu.edu.eg (H.M.S.) \\ 2 Department of Electrical and Computer Engineering, Texas A\&M University, College Station, TX 77843, USA \\ 3 Department of Chemistry, University of Alabama in Huntsville, Huntsville, AL 35899, USA \\ 4 Chemical and Materials Engineering Department, King Abdulaziz University, Rabigh 21911, Saudi Arabia; \\ mzoromba@kau.edu.sa \\ 5 Department of Chemistry, Faculty of Science, Port-Said University, Port Said 42521, Egypt \\ * Correspondence: nouradosoky@gmail.com; Tel.: +1-256-457-0135 \\ + M.G.S. and N.S.D. contributed equally to this work.
}

Received: 29 March 2019; Accepted: 16 May 2019; Published: 20 May 2019

check for updates

\begin{abstract}
The current fossil fuel reserves are not sufficient to meet the increasing demand and very soon will become exhausted. Pollution, global warming, and inflated oil prices have led the quest for renewable energy sources. Algal biofuels represent a potential source of renewable energy. Algae, as the third generation feedstock, are suitable for biodiesel and bioethanol production due to their quick growth, excellent biomass yield, and high lipid and carbohydrate contents. With their huge potential, algae are expected to surpass the first and second generation feedstocks. Only a few thousand algal species have been investigated as possible biofuel sources, and none of them was ideal. This review summarizes the current status of algal biofuels, important steps of algal biofuel production, and the major commercial production challenges.
\end{abstract}

Keywords: biofuels; microalgae; renewable energy; algal cultivation; biofuel conversion

\section{Introduction}

The demand for fossil fuels is anticipated to grow 40\% from 2010 to 2040 [1]. Therefore, to satisfy our energy needs, alternative energy sources have been, and are being, explored. Solar, wind and biomass are the major renewable energy sources. Biomass, derived from a biological precursor, has been used to produce biofuels and bioproducts over the last few decades [2]. Depending on type of biomass, there are first to fourth biofuel generations. Biofuels include biodiesel, bioethanol, biomethanol, biohydrogen, and bioethers (biodimethyl ether, biomethyltetrabutyl ether (bio-MTBE)) and bioethyltetrabutyl ether (bio-ETBE) [3]. According to the U.S. Department of Energy, the major biofuels are bioethanol and biodiesel, both of which represent the first generation of biofuel technology [4]. Several biofuel projects have been funded by U.S.A., Australia and European Union. The United States funded projects in Arizona (2008), New Mexico (2009), Massachusetts (2011) and Florida (2013) while the European Union funded four pilot projects; three of which were from 2011 to 2015/16 and the fourth was from 2012 till 2017 [5].

Agrofuel is the first biofuel generation that used specific cultivated plants including sugarbeet, sugarcane, maize, palm, soybean, and sweet sorghum as feedstocks for production. Agrofuel is produced through yeast fermentation of plant sugars or starch to give bio-ethanol and the extracted plant oils to produce biodiesel [6]. These processes greatly negatively impact both the food and water sectors [7]. Second generation biofuels depended on non-food plants like Jatropha, grass, switchgrass, silver grass and non-edible parts of current crops [8]. In order to reduce land and water utilization and excessive use of harmful pesticides [2], algal biofuel emerged as the third generation of biofuels with 
no competition [9]. The different types of algal biofuels are summarized in Figure 1. The fourth biofuel generation is focused on metabolic engineering of the microalgal genome to maximize the biofuel yields or minimize the cost [6,10]. The leaders in biofuel development and consumption are Brazil, United States, France, Sweden and Germany [11]. Recently, several studies have shown promising results in increasing carbon capture capacity, biomass production, and lipid enhancement in genetically modified microalgae [10,12-14].

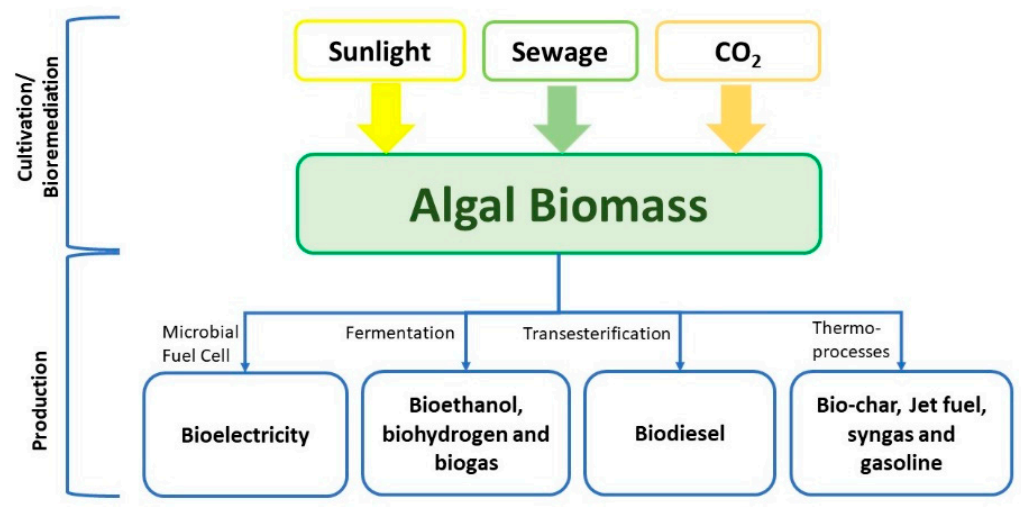

Figure 1. Various scenarios and conversion processes of algae for biofuel production.

\section{Algae}

Algae are aquatic organisms with different species that range in size from microalgae to macroalgae [15] (Figure 2).

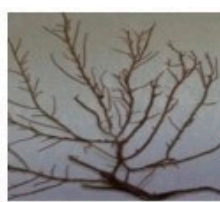

Phaeophyceae (Macroalgae)

Habitat: Marine

Storage: Laminarin

Pigments: Chlorophyll A\&C

Cell wall: Cellulose

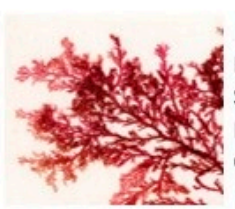

Rhodophyceae (Micro\&Macroalgae)

Habitat: Marine/ freshwater

Storage: Floridean

Pigments: Chlorophyll A\&D

Cell wall: Cellulose (IN) / mucilaginous (OUT)

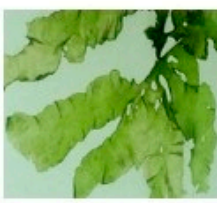

Chlorophyceae (Micro\&Macroalgae)

Habitat: Marine/ freshwater

Storage: Starch

Pigments: Chlorophyll A\&B

Cell wall: Cellulose (IN) / pectose (OUT)

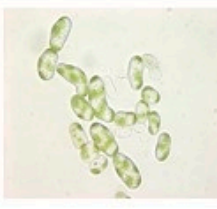

Xanthophyceae (Microalgae)

Habitat: Marine/ freshwater

Storage: Leucosin

Pigments: Chlorophyll A

Cell wall: Cellulose and hemicellulose

https://utex.org/products/utex-0157

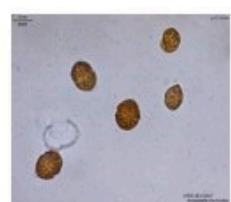

Pyrrophyceae (Microalgae)

Habitat: Marine/ freshwater

Storage: Starch

Pigments: Chlorophyll A\&C

Cell wall: has stiff cellulose plates on the outer surface

https://utex.org/products/utex-lb-1017

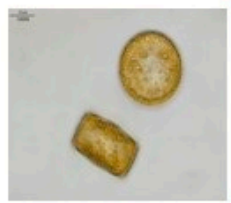

Chrysophyceae (Microalgae)

Habitat: Marine/ freshwater

Storage: Leucosin \& oil drops

Pigments: Chlorophyll A\&C

Cell wall: Cellulose with silicate frustules

https://utex.org/products/utex-lb-fd-0257

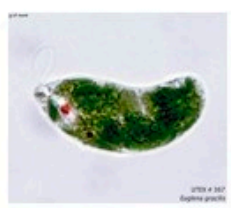

Euglenophyceae (Microalgae)

Habitat: freshwater

Storage: paramylon

Pigments: Chlorophyll A\&B

Cell wall: N/A

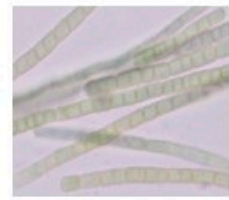

Cyanophvceae (Microalgae)

Habitat: Marine/ freshwater

Storage: Starch \& protein

Pigments: Chlorophyll A\&D

Cell wall: mucopeptide with carbohydrates, amino

acids and fatty acids.

Figure 2. Different groups of algae. Various options are available for algae type and strain choice.

They differ in shapes from a single cell to multicellular structures like filaments and colonies. Most algae can habit any imaginable environment and can withstand extreme conditions [16]. Algae are classified by their development to cyanoprokaryotes and eukaryotes. Cyanoprokaryotes are characterized by the lack of a well-defined nucleus and chloroplasts. Eukaryotic algae are further divided according to cell wall structure, pigments, and storage products into Chlorophyceae, Phaeophyceae, Rhodophyceae, Xanthophyceae, Pyrrophyceae, Euglenophyceae and Chrysophyceae. 
Unlike higher plants, algae have no embryo, vascular tissues or surrounding layer around sex organs. The economic importance of algae is evident in wastewater treatment, production of energy cogeneration, bioremediation, natural fertilizer, animal fodders, medicinal compounds and nutraceuticals. In addition, numerous products can be obtained from algae including proteins, vitamins, pigments, nutraceuticals and special oils (omega-3) [5]. Algae can use light more efficiently, grow faster and can produce 2-15 fold higher lipids than higher plants like Jatropha, rapeseed and soybean [17-20].

\subsection{Microalgal Cultivation}

Algae possess high carbon dioxide sequestering efficacy, high photosynthetic levels and high growth rates. They also use nitrogen and phosphorous from municipal, agricultural, and industrial wastewater which reduces the nutrient load in wastewater. They contain substantial amounts of lipids that can produce nontoxic and highly biodegradable biofuels. Algal cultivation for biofuel production sounds quite simple since algae have relatively simple requirements to grow. However, several factors affect the optimum algal growth and lipid accumulation including micro- and macronutrients (availability and concentration), $\mathrm{CO}_{2}$, temperature, $\mathrm{pH}$, and light (intensity and photoperiod). Algae differ in their reaction to these conditions especially to temperature and light. A temperature between $20-30{ }^{\circ} \mathrm{C}$ is considered suitable for most algal species. The quantity of unsaturated fatty acids decreases with increasing the temperature which is a physiological adaptation [21]. In addition, the type of precursor fatty acids influences several biodiesel properties especially oxidative stability, melting point, heating point, iodine and cetane numbers, and lubricity. The usual targets for qualified biodiesel production are palmitic acid (C16:0), palmitoleic acid (C16:1), stearic acid (C18:0), oleic acid (C18:1), linoleic acid (C18:2), and linolenic acid (C18:3) [22]. Under limiting conditions, some microalgae alter their lipid biosynthesis pathway to make large quantities of neutral lipids (20-50\% of dry weight) typically as triacylglycerol (TAG) and primarily stored in cytosolic lipid bodies [23].

For biofuel production, it is better to survey a large number of algal species first then select the species with higher productivities and optimize all conditions to reach maximum production for these species. Hundreds of experiments can be performed for one species to maximize both its biomass and biofuel production. The selection and optimization processes are usually carried out in a bulk-culture in vitro. Because the conventional lab techniques (Figure $3 \mathrm{~A}$ ) are labor-intensive and time consuming, microfluidics or on-chip technology found its importance. Algae-on-chip relies on estimating a droplet as a vessel of culturing starting with a single cell per droplet (Figure 3B). One of the remarkable advantages of this technique is that the microfluidic device captures more than 100 droplets at once (this number can be increased according to the design). These hundred droplets captured in the same device represent 100 replicates in a space less than $4 \times 4 \mathrm{~cm}$ which is impossible to accomplish by the traditional methods. Different designs can be fabricated to test different culture conditions, and even to extract oil, and DNA. Microfluidics are time and labor saving with high through-put single cell analysis. This technique also allows to test more than one factor rapidly. Despite having some defects, this technique was able to overcome all the disadvantages of the previous techniques [24]. Microfluidic chips have been used for several applications including ecotoxicology screening [25], cell identification [26], cultivation under multiple conditions, lipid analysis [27], sorting [28], trapping, cell viability [29], and quantify self-secreted macromolecules e.g., ethanol [30] and lactate [31]. 

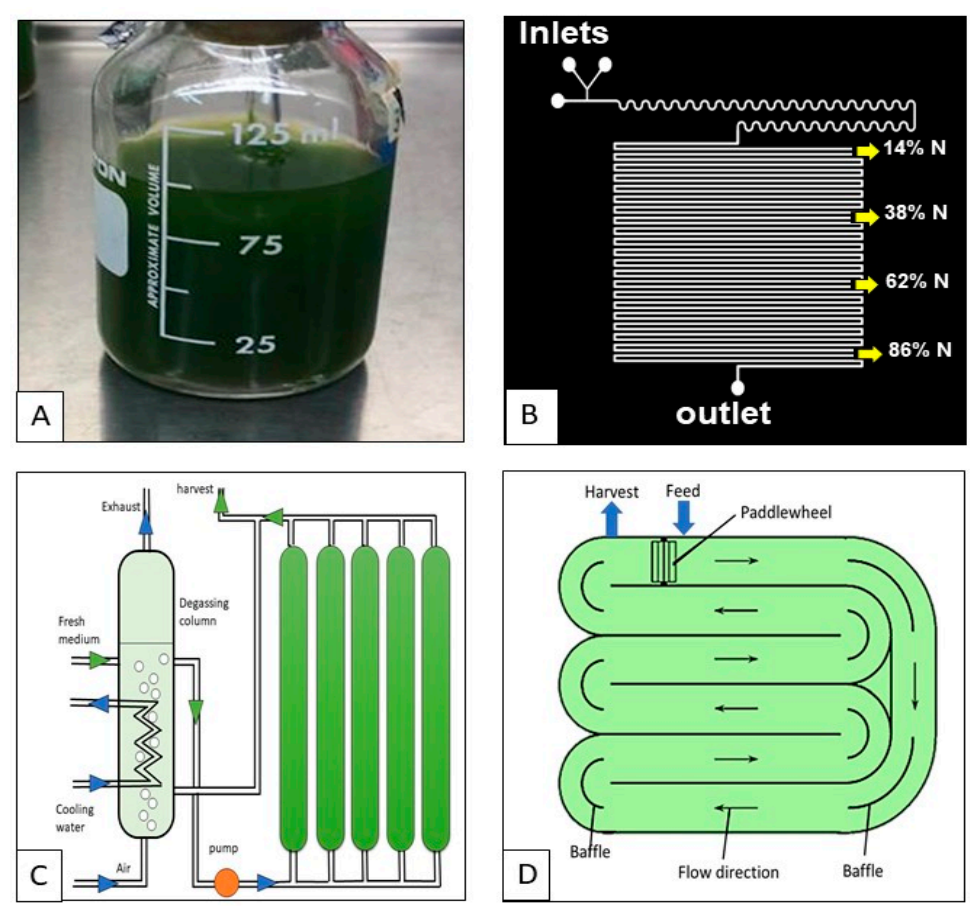

Figure 3. Algal cultivation techniques. (A) Conventional method (in vitro), (B) Lab on-a-chip method (in vitro), (C) Photobioreactor (in vivo), and (D) Open pond (in vivo).

Microalgae cultivation is a significant factor in biofuel production. Cultivation system selection is particularly important since it affects the phytoremediation efficiency and biofuel yield. Generally speaking, photoautotrophic systems can be closed and open (Table 1). Closed systems (photobioreactors (PBRs)) are highly-controlled, high-yield systems intended to allow high light accessibility and perfect stirring [32,33] (Figure 3C). Photobioreactors come in different designs including the flat plate, tubular, or columns, with tubular being the most common [34]. They can be constructed as plastic or glass bags, tanks, or towers. Bubble columns and airlift photobioreactors were reported to give a comparatively higher microalgal biomass. Since excessive oxygen can negatively affect the algal growth, an auxiliary tank is usually added to separate it [19]. While contamination is eliminated [35], the major drawback of these controlled facilities is their cost [34]. Other challenges include overheating, oxygen buildup, difficulty of scaling-up, bio-fouling, and overtime cell damage [16].

On the other hand, open systems (also called open ponds) are less expensive, but less controlled, than the closed systems (Figure 3D). The most commonly used forms are the raceway pond, the circular pond tank, the closed pond, and the shallow big pond. One of the main features of open systems is their ability to utilize the atmospheric $\mathrm{CO}_{2}$. Location of the open system is a very important criterion since it affects sunlight availability. Also, they are usually equipped with a rotating arm to guarantee continuous stirring of the culture [34]. Contamination by bacteria or even other microalgae is the major challenge of these systems [36]. Other drawbacks include poor light penetration, unregulated temperature, evaporation loss, and $\mathrm{CO}_{2}$ diffusion into the atmosphere [16]. However, this system is more affected by variability in light, water temperature, and evaporation. When deciding between these two systems, the comparison is mainly based on the productivity per unit area and the cost. Photobioreactors have higher productivity rates than open ponds due to the controlled growth conditions which ensures good light penetration. Nevertheless, open ponds are cheaper than the closed systems that require infrastructure, operation, and maintenance costs [37]. One of the main advantages of using photoautotrophic systems is the consumption of carbon dioxide as the carbon source. However, if $\mathrm{CO}_{2}$ is used as the only carbon source, it is desirable to have the cultivation as close as possible to facilities that can provide adequate amounts of $\mathrm{CO}_{2}$. Moreover, compared to other cultivation methods, contamination is less severe when using photoautotrophic systems [38]. 
A setup combining an open system and a closed system is known as a hybrid system. Hybrid systems accomplish excellent biomass productivity along with high nutrient removal [39]. They are designed to overcome the huge initial and operating costs of closed systems and the limitations of open systems. In hybrid systems, microalgae are cultured in a closed photobioreactor first then transferred to an open system to enhance the yield [40]. Hybrid systems are appropriate for large algal cultivation [19].

Table 1. Comparison of features and challenges of algal cultivation methods.

\begin{tabular}{|c|c|c|c|}
\hline Cultivation Technique & Type & Advantages & Issues \\
\hline \multirow{2}{*}{$\begin{array}{l}\text { Photoautotrophic } \\
\text { cultivation }\end{array}$} & $\begin{array}{c}\text { Closed } \\
\text { photobioreactors }\end{array}$ & $\begin{array}{ll}\text { - } & \text { Water saving } \\
\text { - } & \text { Greater long-term } \\
\text { culture maintenance } \\
\text { - } & \text { Higher surface to volume } \\
\text { ratio (high yield) }\end{array}$ & $\begin{array}{ll}\text { - } & \text { Expensive } \\
\text { - } & \text { Scalability } \\
\text { - } & \text { Temperature control } \\
& \text { (requires cooling) } \\
\text { - } & \text { Periodic cleaning } \\
\text { - } & \text { Maximum light exposure }\end{array}$ \\
\hline & Open ponds & $\begin{array}{ll}\text { - } & \text { Evaporative cooling } \\
\text { - } & \text { Lower costs }\end{array}$ & $\begin{array}{l}\text { - } \quad \text { Subject changes in humidity } \\
\text { and temperature } \\
\text { - } \quad \text { monocultures are difficult } \\
\text { to maintain } \\
\text { - } \quad \text { Maximum light exposure } \\
\text { - } \quad \text { Low yield }\end{array}$ \\
\hline Heterotrophic cultivation & - & $\begin{array}{ll} & \text { Easy to maintain } \\
- & \text { Contamination prevention } \\
\text { - } & \text { Utilization of inexpensive } \\
& \text { lignocellulosic sugars } \\
\text { - } & \text { High biomass concentrations }\end{array}$ & $\begin{array}{l}\text { Competition with other } \\
\text { biofuel technologies } \\
\text { for feedstock. }\end{array}$ \\
\hline
\end{tabular}

According to their metabolic pathways, algae can be autotrophic, heterotrophic, mixotrophic, and photoheterotrophic [41]. Autotrophic pathway or photosynthesis involves the conversion of inorganic carbon into organic energy in the presence of light [42]. Heterotrophic pathway needs organic carbon to feed in the dark [43] whereas, in mixotrophic pathway, cells can grow autotrophic or heterotrophic based on the available food sources [44]. Photoheterotrophic pathway takes place in the presence of light and organic carbon [42]. Heterotrophic metabolism results in a higher growth rate compared to autotrophic metabolism [45]. It has been reported that mixotrophic metabolism is the best way to get maximum biomass and lipid productivities [46].

\subsection{Algal Harvesting}

Harvesting is the process of collecting algal cells from its medium with no harm to its water content [47]. Several techniques have been used in harvesting algal biomass including flocculation, filtration, flotation, sonication, centrifugation, and precipitation (Table 2). In some cases, two harvesting methods can be combined to improve the biomass. In other cases, dewatering can follow harvesting. Dewatering is the process of removing the water content from cells to get dried mass [48]. 
Table 2. Comparison of theory, advantages and disadvantages of algal harvesting methods.

\begin{tabular}{|c|c|c|c|c|}
\hline Technique & Theory & Advantages & Disadvantage & Reference \\
\hline Flocculation & $\begin{array}{l}\text { Cells are aggregated by } \\
\text { increasing their size using a } \\
\text { flocculant which can be } \\
\text { chemicals (ferric sulfate, ferric } \\
\text { chloride, and ammonium } \\
\text { sulfate), bioagents (chitosan), or } \\
\text { microbes (bacteria). }\end{array}$ & Time-saving & $\begin{array}{ll}\text { - } & \text { Large } \\
\text { occupation space. } \\
\text { - } \\
\text { High cost of } \\
\text { flocculants } \\
\text { and operators. }\end{array}$ & {$[34,49-51]$} \\
\hline Filtration & $\begin{array}{l}\text { Large cells (size }>70 \mu \mathrm{m}) \text { can be } \\
\text { filtered under pressure or } \\
\text { suction whereas smaller cells } \\
\text { (size }<30 \mu \mathrm{m} \text { ) require ultrafilters } \\
\text { to be harvested. Ceramic-coated } \\
\text { membrane sheets can substitute } \\
\text { conventional membranes. }\end{array}$ & - $\quad$ Time-saving & $\begin{array}{l}\text { - } \quad \text { Membrane fouling } \\
\text { and clogging }\end{array}$ & [52] \\
\hline Flotation & $\begin{array}{l}\text { Trapping algal cells by } \\
\text { bubbling air }\end{array}$ & $\begin{array}{l}\text { - Less expensive than } \\
\text { other methods }\end{array}$ & $\begin{array}{l}\text { Depends on bubble } \\
\text { distribution into } \\
\text { the suspension. }\end{array}$ & [34] \\
\hline Sonication & $\begin{array}{c}\text { Pumping organisms } \\
\text { continuously into a resonator } \\
\text { chamber due to acoustic forces. }\end{array}$ & $\begin{array}{ll} & \text { non-fouling } \\
\text { - } & \text { no shear } \\
\text { - } & \text { no freely } \\
\text { moving parts } \\
\text { - } & \text { possibility of } \\
\text { continuous operation } \\
\text { - } & \text { no cell harming } \\
\text { - } & \text { small occupation } \\
\text { space }\end{array}$ & $\begin{array}{l}\text { High power } \\
\text { consumption due to } \\
\text { cooling system } \\
\text { High cost of } \\
\text { large-scale system. }\end{array}$ & {$[53,54]$} \\
\hline Centrifugation & $\begin{array}{l}\text { Sedimentation based on the } \\
\text { velocity, cell size, and density }\end{array}$ & $\begin{array}{ll}\text { - } & \text { Suitable for } \\
\text { large microalgae } \\
\text { - } \quad \text { Rapid }\end{array}$ & $\begin{array}{l}\text { - Contains freely } \\
\text { moving parts }\end{array}$ & {$[34,40,55]$} \\
\hline Precipitation & $\begin{array}{l}\text { Some algae are self-precipitated. } \\
\text { They settle at the bottom after } \\
\text { stopping circulation. }\end{array}$ & $\begin{array}{l}\text { It doesn't require } \\
\text { energy or chemicals. } \\
\text { - } \quad \text { It happens naturally. }\end{array}$ & $\begin{array}{ll}\text { - } & \text { Species-specific } \\
\text { - } & \text { Time periods } \\
\text { depend on species. } \\
\text { - } \quad \text { Not all species } \\
\text { are self-precipitated. }\end{array}$ & [3] \\
\hline
\end{tabular}

\subsection{Algal Fuels}

As the third generation feedstock, microalgae have a huge potential for biofuel production due to their quick growth, great biomass yield, and high lipid and carbohydrate contents. Biodiesel, biogas, bioethanol, and biomethane are among the valuable biofuels produced by algae (Table 3). Algal carbohydrates are used for producing bioethanol, while algal oils are used for biodiesel production. The remaining biomass is used for methane or fuel oil production. After biofuel production, the residual biomass can be used to produce nutraceuticals, protein supplements, therapeutics, eicosapentaenoic acid (EPA), docosahexaenoic acid (DHA), biocontrol agents, fertilizers, and animal feed. Biodiesel is a biodegradable fuel that reduces sulfur and particulate matter emissions while having engine performance similar to petroleum [56]. Biogas or biomethane is produced through the anaerobic digestion of organic matter. Biogas is chiefly made of methane $(65-75 \%)$ and carbon dioxide $(25-35 \%)$ [57]. The anaerobic digestion process involves (1) biopolymer hydrolysis by hydrolytic bacteria to monosaccharaides, (2) conversion of the monosaccharaides into acids through fermentation, (3) formation of acetate by action of acetogenic bacteria, and (4) formation of methane and carbon dioxide by methanogenic bacteria [58]. Microalgal hydrocarbons can be converted to kerosene, diesel, and gasoline. For example, Botryococcus braunii produces hydrocarbons with excellent oil yield outside the cell which is more convenient for extraction [59]. In the presence of air, oxygen, or water vapor, bio-syngas is produced by the biomass gasification to give methane, hydrogen, carbon monoxide, water and ashes [60]. The gasification process requires a high temperature of $800-1200{ }^{\circ} \mathrm{C}$. It is desirable that the biomass water content is below $20 \%$ [61]. In absence of oxygen, microalgae can directly produce hydrogen, as a promising source of clean energy that does not emit greenhouse gasses, from 
sunlight and water [62]. Bioethanol is obtained from fermenting sugars by yeast. Some microalgae were reported to have starch content above $50 \%[63,64]$. The yield of polysaccharides in seaweeds was 3.6-11.7 g/L and 179-260 mg/g [65]. Microalgal cellulose and hemicellulose can be converted to sugars and then ethanol [66].

Table 3. Oil, gas, and char from different algae species.

\begin{tabular}{|c|c|c|c|}
\hline Biofuel Type & Algal Species & Experimental Conditions & Reference \\
\hline \multirow{10}{*}{ Biodiesel } & Chlorella sp. & $60^{\circ} \mathrm{C}, 4 \mathrm{~h}, \mathrm{H}_{2} \mathrm{SO}_{4}, \mathrm{MeOH}$ & [67] \\
\hline & Chlorella pyrenoidosa & $90^{\circ} \mathrm{C}, 2 \mathrm{~h}, \mathrm{H}_{2} \mathrm{SO}_{4}, \mathrm{MeOH}$ & [68] \\
\hline & Dunaliella tertiolecta & $110^{\circ} \mathrm{C}, 5 \mathrm{~h}, \mathrm{H}_{2} \mathrm{SO}_{4}, \mathrm{MeOH}-\mathrm{THF}$ & [69] \\
\hline & Nannochloropsis oculata & $80^{\circ} \mathrm{C}, 2 \mathrm{~h}, \mathrm{NaOH}, \mathrm{MeOH}$ chloroform (10:1) & [70] \\
\hline & Spirulina sp. & $\begin{array}{l}\text { Catalyst concentration, methanol }=80 \mathrm{~mL} \text {, } \\
\text { reaction time }=8 \mathrm{~h} \text {, at } 65^{\circ} \mathrm{C} \text { and } 650 \mathrm{rpm}\end{array}$ & [71] \\
\hline & Schizochytrium limacinum & $90^{\circ} \mathrm{C}, 40 \mathrm{~min}, \mathrm{H}_{2} \mathrm{SO}_{4}, \mathrm{MeOH} /$ chloroform & [72] \\
\hline & Dictyochloropsis splendida & $110^{\circ} \mathrm{C}, 5 \mathrm{~h}, \mathrm{NaOH}, \mathrm{MeOH}$ & [73] \\
\hline & $\begin{array}{l}\text { Desmodesmus } \\
\text { quadricaudatus and } \\
\text { Chlorella sp. }\end{array}$ & $\begin{array}{l}\text { Pure batch cultures, BG-11 standard and } \\
\text { nitrogen-free medium, hexane-ether, } \\
\text { methanol }\end{array}$ & [15] \\
\hline & $\begin{array}{l}\text { Desmodesmus } \\
\text { quadricaudatus and } \\
\text { Chlorella sp. }\end{array}$ & $70{ }^{\circ} \mathrm{C}, 180 \mathrm{~min}, \mathrm{H}_{2} \mathrm{SO}_{4}, \mathrm{MeOH}$ & [74] \\
\hline & Oscillatoria sp. & $\begin{array}{c}\text { BG-11 medium with different nitrate } \\
\text { concentrations; }(1500,375,186,94,47,23 \text { and } \\
0.0 \mathrm{mgL}^{-1} \mathrm{NaNO}_{3}\end{array}$ & [75] \\
\hline \multirow[t]{2}{*}{ Bioethanol } & Chlamydomonas reinhardtii & $\begin{array}{l}\text { Enzyme pretreatment, } 70-100{ }^{\circ} \mathrm{C}, 30 \mathrm{~min} \text {, } \\
\text { S. cerevisiae S } 288 \mathrm{C} \text { cultured anaerobically at } \\
30^{\circ} \mathrm{C} \text { for } 40 \mathrm{~h} \text {, rotation of } 160 \mathrm{rpm}\end{array}$ & [76] \\
\hline & Chlorococcum sp. & $\begin{array}{c}\text { Yeast powder, } 30^{\circ} \mathrm{C}, 200 \mathrm{rpm}, 60 \mathrm{~h}, \\
\text { no pretreatment }\end{array}$ & [65] \\
\hline \multirow[t]{3}{*}{ Biohydrogen } & Anabaena cylindrical & $\begin{array}{l}\text { pretreatment with amylase followed by } \\
\text { thermophilic fermentation under light } \\
\text { intensity of } 120 \mathrm{mmol} / \mathrm{m}^{2} / \mathrm{s}\end{array}$ & [77] \\
\hline & Mastigocladus laminosus & $\begin{array}{l}\text { Sparging the cultures with a gas mixture of } \\
0.2 \text { to } 0.4 \% \mathrm{~N}_{2}, 0.6 \% \mathrm{CO}_{2} \text {, and balance argon, } \\
\text { gas flow rate }=3 \mathrm{~L} / \mathrm{h}\end{array}$ & [78] \\
\hline & Chlamydomonas reinhardtii & $\begin{array}{l}\text { Aerobic and anaerobic phases, light intensity } \\
\qquad \begin{array}{l}\left(70 \times 2 \mathrm{mmol} / \mathrm{m}^{2} / \mathrm{s}\right), \text { mixing speed of } \\
170 \pm 10 \mathrm{rpm} / 2.5 \mathrm{~min}\end{array}\end{array}$ & [58] \\
\hline \multirow{11}{*}{ Bio-oil } & Chlorella sp. & $300^{\circ} \mathrm{C}, 90 \mathrm{~min}$ & [79] \\
\hline & Chlorella vulgaris & $300^{\circ} \mathrm{C}, 60 \mathrm{~min}$ & [80] \\
\hline & Chlorogloeopsis fritschii & $300^{\circ} \mathrm{C}, 60 \mathrm{~min}$ & [80] \\
\hline & Nannochloropsis sp. & $300^{\circ} \mathrm{C}, 90 \mathrm{~min}$ & [79] \\
\hline & Nannochloropsis oculata & $350^{\circ} \mathrm{C}, 60 \mathrm{~min}$ & [80] \\
\hline & Nannochloropsis gaditana & $375^{\circ} \mathrm{C}, 5 \mathrm{~min}$ & [81] \\
\hline & Spirulina platensis & $300^{\circ} \mathrm{C}, 60 \mathrm{~min}$ & [80] \\
\hline & Tetraselmis sp. & $350^{\circ} \mathrm{C}, 5 \mathrm{~min}$ & [82] \\
\hline & Bacillariophyta sp. & $325^{\circ} \mathrm{C}, 60 \mathrm{~min}$ & [83] \\
\hline & Cyanobacteria sp. & $325^{\circ} \mathrm{C}, 45 \mathrm{~min}$ & [83] \\
\hline & Desmodesmus sp. & $375^{\circ} \mathrm{C}, 5 \mathrm{~min}$ & [84] \\
\hline
\end{tabular}


Table 3. Cont.

\begin{tabular}{|c|c|c|c|}
\hline Biofuel Type & Algal Species & Experimental Conditions & Reference \\
\hline & Scenedesmus dimorphus & $350^{\circ} \mathrm{C}, 60 \mathrm{~min}$ & [80] \\
\hline & Porphyridium cruentum & $350^{\circ} \mathrm{C}, 60 \mathrm{~min}$ & [81] \\
\hline & Phaeodactylum tricornutum & $375^{\circ} \mathrm{C}, 5 \mathrm{~min}$ & [79] \\
\hline Ethanol & Chlorella vulgaris & $\begin{array}{l}\text { Pellet washed with methanol (95\%), } \\
\text { incubated with } \alpha \text {-amylase }\left(100^{\circ} \mathrm{C} \text { and } \mathrm{pH} \text { 6) }\right. \\
\text { and glucoamylase }\left(60^{\circ} \mathrm{C} \text { and } \mathrm{pH} 4.5\right), \\
\text { fermented by Saccharomyces cerevisiae (IFO } \\
\text { 309), pretreatment (ultrasonic radiation). }\end{array}$ & [85] \\
\hline Gas & Emiliania huxleyi & Pyrolysis, batch cultivation, fixed bed, $400^{\circ} \mathrm{C}$ & [86] \\
\hline \multirow{5}{*}{ Methane } & Chlorella vulgaris & $\begin{array}{c}308^{\circ} \mathrm{C}, 30 \text { days, Batch culture, pretreatment } \\
\text { (Thermal } 40 \text { min/alkali) }\end{array}$ & {$[60]$} \\
\hline & Spirulina sp. & $308^{\circ} \mathrm{C}, 28$ days, Batch, no pretreatment & [87] \\
\hline & Scenedesmus obliquus & $\begin{array}{l}306^{\circ} \mathrm{C}, 20 \text { days, Anaerobic Membrane } \\
\text { Bioreactor, no pretreatment }\end{array}$ & [87] \\
\hline & Arthrospira maxima & $\begin{array}{l}308^{\circ} \mathrm{C}, 2-4 \text { days, Continuous Flow } \\
\text { Stirred-Tank Reactor, pretreatment } \\
\text { (Magnetic stirred and dried) }\end{array}$ & [88] \\
\hline & Euglena gracilis & $30{ }^{\circ} \mathrm{C}, 150 \mathrm{mmol} / \mathrm{m}^{2} / \mathrm{s}$ & [89] \\
\hline \multirow{2}{*}{ Oil } & Chlorella protothecoides & Slow pyrolysis, tubular reactor, $550^{\circ} \mathrm{C}$ & [90] \\
\hline & Microcystis aeruginosa & Fast pyrolysis, $10^{\circ} \mathrm{C} / \mathrm{min}, 500^{\circ} \mathrm{C}$ & [91] \\
\hline Oil/gas & Chlorella sp. & Pyrolysis, fixed bed reactor, $450^{\circ} \mathrm{C}$ & [92] \\
\hline \multirow{5}{*}{ Oil/gas/char } & Chlorella vulgaris & $\begin{array}{l}\text { Closed tubular photobioreactor. Fast } \\
\text { pyrolysis, fluidized bed, } 500{ }^{\circ} \mathrm{C}\end{array}$ & [93] \\
\hline & Dunaliella tertiolecta & Pyrolysis, fluidized bed, $10^{\circ} \mathrm{C} / \mathrm{min}, 500^{\circ} \mathrm{C}$ & [94] \\
\hline & Nannochloropsis sp. & $\begin{array}{l}\text { Pyrolysis, fixed bed reactor with/without } \\
\text { HZSM- } 5,10^{\circ} \mathrm{C} / \mathrm{min}, 40{ }^{\circ} \mathrm{C}\end{array}$ & [95] \\
\hline & Synechococcus & Pyrolysis, $500^{\circ} \mathrm{C}, 10^{\circ} \mathrm{C} / \mathrm{min}$ & [94] \\
\hline & Tetraselmis Chuii & IR-pyrolysis, fixed bed, $500^{\circ} \mathrm{C}, 10^{\circ} \mathrm{C} / \mathrm{min}$ & [96] \\
\hline \multirow{7}{*}{ Syngas } & Chlorella vulgaris & $450^{\circ} \mathrm{C}, 30 \mathrm{~min}$, Batch reactor & [97] \\
\hline & Nannochloropsis sp. & $\begin{array}{c}\text { Fixed bed, } 700-1000^{\circ} \mathrm{C}, 1 \mathrm{e} 10 \mathrm{bar}, \\
10,000{ }^{\circ} \mathrm{C} / 1 \mathrm{~min},\end{array}$ & [98] \\
\hline & Nannochloropsis oculata & Fixed bed reactor, $850^{\circ} \mathrm{C}, 15 \mathrm{~min}, \mathrm{Fe}_{2} \mathrm{O}_{3}, \mathrm{CO}_{2}$ & [99] \\
\hline & Nannochloropsis gaditana & $850^{\circ} \mathrm{C}, \mathrm{TGA}$ & [100] \\
\hline & Spirulina platensis & $\mathrm{Ru} / \mathrm{ZrO}_{2} ; \mathrm{Ru} / \mathrm{C},>400^{\circ} \mathrm{C}$ & [101] \\
\hline & Saccharina latissimi & $450^{\circ} \mathrm{C}, 30 \mathrm{~min}, \mathrm{NaOH}$, Ni Batch reactor & [97] \\
\hline & Tetraselmis sp. & $\begin{array}{c}\text { Fixed bed reactor, } 850{ }^{\circ} \mathrm{C} \text {, co-gasification } \\
(10 \% \text { algae and } 90 \% \text { coal })\end{array}$ & [102] \\
\hline
\end{tabular}

\subsection{Conversion Techniques}

Algae are significant candidates for biofuel production [23,103,104]. Different products can be obtained from algae according to species type, cultivation system and processing of biomass. Energy products from algae include biodiesel, biokerosene (jet fuel), gasoline, ethanol, methanol, hydrogen and syngas [5]. Algae can be processed in different ways to create an array of end-use energy products. After harvesting, algal biomass can be processed through thermochemical [105], biochemical, transesterification, and photosynthetic microbial fuel cell conversion processes [106]. 


\subsubsection{Thermochemical Conversion}

Thermochemical conversion processing involves the thermal breakdown of biomass then organic chemical reformation into biofuels through pyrolysis, gasification, combustion or hydrothermal liquefaction [2,106]. Pyrolysis is a thermal decomposition of biomass to produce solid fuel (biochar), liquid fuel, and gaseous fuel products in the absence of oxygen [16]. Pyrolysis could be slow (a slow heating rate of $0.1-1{ }^{\circ} \mathrm{C} / \mathrm{s}$ for long duration), fast (a fast heating rate of $10-200^{\circ} \mathrm{C} / \mathrm{s}$ in a short duration), or flash (a very fast heating rate of $>1000{ }^{\circ} \mathrm{C} / \mathrm{s}$ for a very short duration). Typically, it happens at a rate of $300-700^{\circ} \mathrm{C} / \mathrm{s}[29,107,108]$. Taking into consideration the high ash content of algae, pyrolysis is the most preferred conversion process but the produced oil still has some issues with its acidity, viscosity, and stability [16]. The microwave enhanced pyrolysis (MEP) has been recommended as a quick, efficient method for bio-oil production [109]. Gasification is the partial oxidation of algal biomass with a controlled quantity of oxygen, steam or air at $700-1000{ }^{\circ} \mathrm{C}$ [106] that results in a syngas (a mixture of different gases mainly $\mathrm{H}_{2}, \mathrm{CO}, \mathrm{CO}_{2}$, and $\mathrm{CH}_{4}$ ) [2]. Direct combustion involves oxygenation of biomass in a boiler, furnace, or steam turbine at a temperature around $1000{ }^{\circ} \mathrm{C}$ to produce hot gases. Prior to the combustion stage, pre-treatments like drying and grinding into smaller particles are required [16]. In the hydrothermal liquefaction, algal slurries are exposed to $300-400{ }^{\circ} \mathrm{C}$ and $40-200$ bar to produce biocrude, gas, and char (10-73, 8-20, and 0.2-0.5\%, respectively) [110-114]. Several compounds can be extracted or depolymerized from the algal biomass via liquefaction [115]. Oil yield from hydrothermal liquefaction is in the range of $9-97 \%[116,117]$ which is higher than the pyrolysis bio-oil [118].

\subsubsection{Biochemical Pathways}

The biochemical pathway of conversion involves hydrolysis of cell walls by bacteria into fermentable sugars [2]. Fermentation refers to the anaerobic digestion of sugars into biogas, bioethanol, or biohydrogen. Biogas is produced through acetogenesis in which all the fermentable products are oxidized into acetate which is converted during methanogenesis into methane and $\mathrm{CO}_{2}$ [16]. Biogas production is influenced by carbon nitrogen $(\mathrm{C}: \mathrm{N})$ ratio in the feedstock, duration, temperature, $\mathrm{pH}$, solids, and feeding rates [2]. The biogas yield is rather small due to the algal sensitivity to degradation by bacteria and low $\mathrm{C}: \mathrm{N}$ ratio, which results in the production of ammonia (inhibitor). Interestingly, the lipid-free and amino acid-free residual biomass of Scenedesmus spp. gave better biogas yield compared to the raw one [119]. To overcome the lower C:N ratio, the biomass is usually co-digested with waste papers and sewage sludge [36,120]. This co-digestion was reported to increase the $\mathrm{CH}_{4}$ production by $26 \%$ [121]. The use of salt-adapted micro-organism was reported to attenuate the effect of high protein content on anaerobic digestion [34]. Microwave pre-treatment of biomass can increase biogas yield by $56 \%$ via altering the cell wall structure [122]. Methane production can be enhanced by enzymatic, mechanical and thermal pretreatments $[67,123]$.

Bioethanol is obtained from yeast fermentation of hydrolyzed carbohydrates [124]. Glycogen-containing cyanobacteria were examined for bioethanol production and resulted in $6.5 \mathrm{~g} / \mathrm{L}$ and $350 \mathrm{mg} / \mathrm{g}$ [125]. Phaeophyceae is considered the most appropriate feedstock for bioethanol production owing to its high sugar content $[33,126]$. Pre-treatments like milling, hot water wash, liquefaction, enzymatic hydrolysis, and saccharification or alginate extraction are essential for efficient bioethanol production $[33,127,128]$. Oxygen, as a photosynthesis byproduct, can suppress the hydrogenase pathway [129], nevertheless, anaerobic digestion can conquer this problem [130]. Interestingly, a significant increase in hydrogen production (20-fold) was reported in continuous flow regime compared to batch production [131].

\subsubsection{Transesterification}

Transesterification is the process wherein triglycerides react with an alcohol (commonly methanol or ethanol) in the presence of an acidic or a basic catalyst to give biodiesel and glycerol [132] (Scheme 1). The reaction highly depends on alcohol type, catalysts type, and molar ratio. This process is important 
to reduce algal oil viscosity and increase its fluidity in order to be mixed with petroleum diesel and applied directly to engines [16]. Conventional transesterification involves extraction of algal lipids then esterification whereas direct transesterification is a single-step method where the wet biomass is treated directly without extraction. Biodiesel yield from direct transesterification is usually much lower than the conventional methods although it saves reagents, energy, and time. To save energy, it is best to combine microwave and ultrasound irradiation techniques which will increase the yield to $90 \%$. The use of in situ supercritical methanol transesterification method has been reported as another way to reduce the cost $[133,134]$. The main fatty acids used in producing qualified biodiesel are palmitic acid (C16:0), stearic acid (C18:0), oleic acid (C18:1), linoleic acid (C18:2), and linolenic acid (C18:3) [135]. Biodiesel properties are strongly influenced by its fatty acids content. Polyunsaturated fatty acids (PUFAs) are not favorable because of their susceptibility to oxidation, and saturated lipids tend to elevate the cloud point and viscosity of biodiesel [136], therefore, monounsaturated fatty acids (MUFAs) are the most desired lipids [137]. Heat of combustion, melting point, and viscosity of biodiesel increase with the length of the fatty acid chain and inversely correlated to unsaturation [136]. Autoxidation and lubricity increase with increasing unsaturation [138]. Lipase, as a catalyst in transesterification, catalyzes both esterification and transesterifications simultaneously and helps excluding byproduct recovery $[139,140]$. Chlorophytes, diatoms, and cyanobacteria with high lipid content have great potential in biodiesel production [141]. Oleaginous strains (at least 20\% lipid content on dry weight basis) can overproduce lipids (up to $70 \%$ lipids on dry weight basis) under specific severe stress conditions such as nitrogen and/or silicon (Si) deprivation.<smiles>[R]C(=O)OCC(COC(=O)OC([R])=O)OC([R])=O</smiles>

Scheme 1. A typical transesterification reaction.

\subsubsection{Photosynthetic Microbial Fuel Cell}

In recent years, microbial fuel cells (MFCs) were developed a result of the imminent energy crisis $[142,143]$. MFC activity depends on photosynthetic oxygen generated at cathode to cause increment in the electron transfer from the anode [144] (Figure 4). The limiting factor in traditional MFC is the mechanical aeration at the cathode, employed as a terminal electron acceptor (TEA). The application of algal photosynthesis at the cathode to substitute for the energy-intensive mechanical aeration was reported [145-150]. The synergy between bacterial fermentation at the anode and the oxygenic photosynthesis of microalgae at the cathode supports decent power output [142]. During the day, the algal photosynthetic activity also results in elevating dissolved oxygen (DO) concentration. DO contributes to enhancing the reduction reaction rates at the cathode, which in turn improves bio-electrogenic activity. During night-time, the small DO levels lead to a drop in power output [142]. 


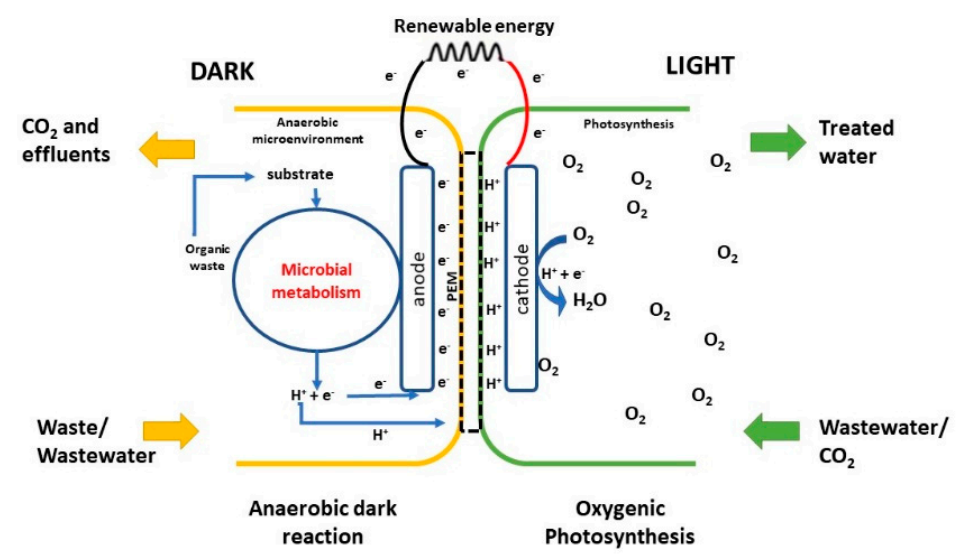

Figure 4. Diagram of a microbial fuel cell (MFC).

\section{Genetic Engineering Toward Biofuels}

Genetic engineering techniques, especially stable heterologous gene expression and genetic transformation, are required to advance algal biofuel production. Acetyl-CoA carboxylase (ACCase) catalyzes the first step in fatty acid synthesis, however, overexpression of this gene alone is not enough to enhance oil production in algae [151,152]. ACCase was overexpressed in Cyclotella cryptica which led to a slight increase in lipid content [151]. Interestingly, a significant increase in algal lipids was reported with the overexpression of diacylglycerol acyltransferase (DAGAT) [153]. In addition, C. reinhardtii was reported to accumulate a high lipid content if the metabolic pathways of starch had been blocked [154,155]. A similar result was observed for Chlorella pyrenoidosa [156]. It would be interesting to see how the lipid content would be affected by activating ACCase, activating DAGAT, blocking starch pathway, and increasing lipid synthesis.

Enhancement of hydrogen production via genetic engineering has been reported by decreasing the light antenna harvesting size, and inhibiting hydrogenase $[157,158]$. A mutant strain of Chlamydomonas reinhardtii (Stm6) with a blocked cyclic electron flow through Photosystem I (less competition for electrons; anaerobiosis), showed increased accumulation of starch and decrease intracellular concentrations of oxygen (hydrogenase inhibitor) [159]. Anaerobiosis can be achieved by a copper responsive nuclear transgene [160]. To overcome the light penetration limitation, a single RNAi construct was able to effectively silence all twenty light-harvesting complex (LHC) protein isoforms of C. reinhardtii increased light transmittance in the culture by $290 \%$ [161]. However, the modified cell density did not increase [162]. Growing algae under heterotrophic or mixotrophic settings results in greater cell densities, thus decreased harvesting cost [163]. While most algae are strict autotrophs [162], Volvox carteri, Phaeodactylum tricornutum, Cylindrotheca fusiformis and C. reinhardtii were effectively transformed with a hexose transporter (HUP1) causing glucose transport into the cells [164-167]. Complete and on-going projects for the whole genome identification of different algal species as C.reinhardtii, Thalassiosira pseudonana, and Micromonas pusilla provide information to understand algal behavior and structure [168]. Technological interventions of genetic and metabolic engineering, and synthetic biology have the potential to generate renewable fuel sources that do not compete with food industry or involve fresh water or agricultural land [169].

\section{Current Status and Challenges}

Bioprospecting for microalgae to produce economically affordable biofuel includes identifying high-lipid producing microalgae from diverse habitats according to temperature and location (Figure 5) [169]. Generally, algal biofuels possess no or very little negative impact on the environment [16]. In fact, the biofuel production process could be associated with other environmental applications including bioremediation (wastewater treatment), electricity or heat production, bio-fixation ( $\mathrm{CO}_{2}$ removal), biofertilizer, animal fodders, healthcare and food products [16]. Algae 
are the most sustainable fuel feedstock that can help in decreasing greenhouse gasses [36]. Because $\mathrm{CO}_{2}$ emissions from liquid fuels was $36 \%$ in 2012 [126,170] which might get up to 45,000 mega tons by 2040 [1], the European Union Renewable Energy Directive (RED) recommended making up to 15\% of energy from renewable sources [170] aiming to considerably decrease greenhouse gas emissions to $20 \%$ by 2050 [171]. UAE proposed running about $10 \%$ of its transport on biofuels by 2020 . The U.S. proposed to replace $20 \%$ of its road transport fuel with biofuel by 2022 and a Renewable Transport Fuel Certificate (RTFC) would be granted for fulfilling this requirement [172]. By the year 2070, renewable energy is expected to dominate [16]. The future of algal biofuels relies on the establishment of cost-effective technologies for commercialization. However, the most appealing solution is to use genetically-engineered algae with precursor overproduction rates and fast growth rates. These species can be introduced to the environment in an open pond that is close to a polluted area. This open pond could be the first step of water purification in a wastewater plant. The biomass slurry from this pond will be used to produce biofuels and the spent biomass can be used as animal feeder or fertilizers.

Algal biofuels might seem unsustainable and too expensive, and their production needs a lot of water, nitrogen, phosphorous, and $\mathrm{CO}_{2}$ but as we mentioned previously, they are environmentally friend with no competition on land or water resources. Table 4 summarizes the environmental, economic, social, and cultural impacts of large-scale algal oil production. Large-scale cultures for biofuel production require a lot of tools, equipment, energy, water and nutrients for each step separately. Large-scale algal cultures and large-scale agriculture could use the same amount of nutrients [173].

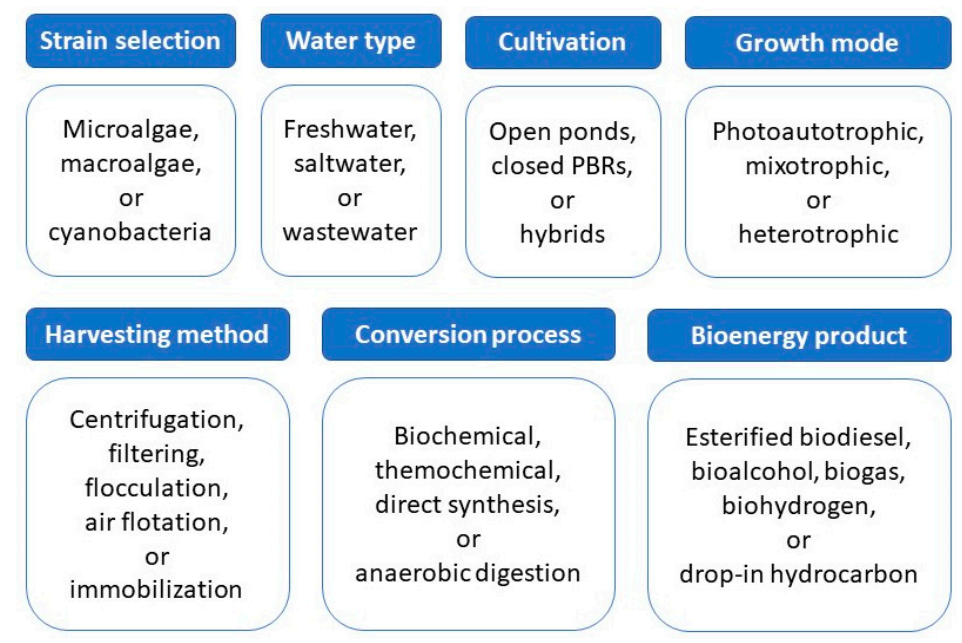

Figure 5. Several options are available for algae type and strain choice, the water source, cultivation method, growth mode, harvesting, biofuel conversion process, and bioenergy product.

Replacing only $5 \%$ of gasoline/diesel with algal biofuels could require about 123 billion to 143 trillion liters of water. The use of wastewater not only prevents the competition with food and feed crops, but also provides some of the nitrogen and phosphorous. However, a major drawback is that wastewater may contain algal pathogens and predators, heavy metals, and other contaminants. Also, most algae production sites exist far away from wastewater treatment plants rendering it unfeasible, costly, and energy-intensive to carry low-quality water for long distances. Moreover, water will not be completely recycled [173]. The most promising scenario is to couple wastewater treatment with biofuel production [174]. Algae can require about $31-46$ pounds $(14-21 \mathrm{~kg})$ of $\mathrm{CO}_{2}$ [173], 6-15 $\times 10^{9} \mathrm{~kg}$ of nitrogen and $1-2 \times 10^{9} \mathrm{~kg}$ of phosphorus per gallon of biodiesel [175]. Several industrial sources of $\mathrm{CO}_{2}$ contain heavy metals like lead, mercury, arsenic, cadmium. Algae are exceptional at absorbing these toxic elements, however, the residual coproduct cannot be utilized as animal fodder. Interestingly, the land required to culture sufficient algal biomass to replace around $5 \%$ of petroleum (which is equivalent to 10 billion gallons) in the U.S. is about 1.5 million acres in the U.S. southwest, 2.2-2.4 million acres in Georgia/Florida and U.S. Midwest, and 4.8 million acres in Texas [173]. 
Another challenge is the choice of algal strains. Site selection, isolation, purification and identification of natural microalgal assemblies are usually time consuming and tedious. For superior microalgal proliferation, the media and cultural conditions need to be optimized to the species of interest. Species identification often involves both morphological and genetic characterization. Taking notes of the environmental conditions at the sampling site is essential to optimize the in vitro experiments. The isolated microalgal strain is then grown in upscale systems for biomass and lipid production [176]. One way to solve this problem is to culture the organisms to their original habitats with enough inoculum [37]. In addition, algae that perform well in vitro might not survive in the field, especially bio-engineered algae which are more vulnerable to infections and predators.

The energy cost of algal extraction is ten-fold higher than the energy cost of soybean oil extraction. The cost was reported in 2012 to be $\$ 27$ per gallon [177]. Even when flawless planning and setup are implemented, the cost of a barrel would be $\$ 800$. The energy return on investment (EROI) is a measure of sustainability. EROI is the ratio between the energy from a certain energy resource and the exergy spent to obtain that resource. In case of EROEI $<1$, the energy required to produce a fuel is higher than energy present in the fuel and coproducts. Algal fuels with an EROEI $<1$ are undoubtedly unsustainable. An EROI $>3$ is desirable for a fuel to be a sustainable energy source [178]. The estimated EROI for algal biofuels produced in either open ponds or photobioreactors is 0.13 to 0.71 [173]. The energy required to scale up algal biofuels production include constructing the facility, chemicals, pumps, cooling, $\mathrm{CO}_{2}$ pipelines, filters, harvesting, centrifuges, storage, surface structure for open ponds, $\mathrm{pH}$, salinity, extraction and conversion, transport, recycling water and nutrients, and delivering fuels $[179,180]$.

Table 4. Environmental, economic, social, and cultural effects of large-scale algal oil production.

\begin{tabular}{|c|c|}
\hline Dimension & Issues \\
\hline Environmental dimension & 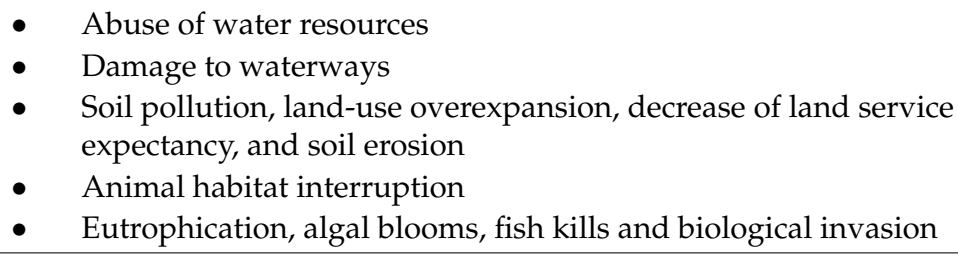 \\
\hline Economic dimension & $\begin{array}{ll}\text { - } & \text { Expensive start-up phase } \\
\text { - } & \text { Requires huge investments for maintenance }\end{array}$ \\
\hline Social dimension & $\begin{array}{l}\text { - Water pollution might affect local wildlife, farm animals, } \\
\text { and people } \\
\text { - } \quad \text { Safety concerns about genetically modified algae } \\
\text { - Disease spread }\end{array}$ \\
\hline Cultural dimension & $\begin{array}{l}\text { - It takes time to get people to accept unconventional } \\
\text { microalgae utilization }\end{array}$ \\
\hline
\end{tabular}

\section{Biorefinery/Valorization}

Biorefining means breaking down biomass into bioproducts—either fuel or nonfuel products-via sustainable methods [181]. Depending on the target product, a variety of refinery schemes are available [182]. Successful scenarios for algal refineries have been established for nonfuel products, but not for biofuel production as a consequence of the huge costs of cultivation, harvesting and transforming processes [2]. Other cost-effective alternatives have been employed. For example, cultivation of algae using industrial $\mathrm{CO}_{2}$ or nutrients coming from sewage, harvesting biomass by aggregation through flocculation and coagulation or by gravity filtration [2]. Another strategy is use chemical or mechanical pretreatments that can eliminate some steps of the original process [182,183]. The most comprehensive biorefinery scheme is the production of the target product with high-value co-products [184]. A good example on valorization is the production of biogas, biohydrogen, and bioethanol as well as food products and fertilizers from algal biomass residue after biodiesel 
production [176,185]. The combination of biofuel production reduces the cost by $33 \%$ [2]. The synergy approach makes the technology more viable and more economically feasible [186]. In addition, algae are excellent sources of proteins that can compete with plant and animal proteins [182]. All these products along with phytoremediation, where algae used industrial carbon dioxide and sewage water for cultivation, can be achieved [187].

\section{Conclusions}

Algae are attractive sources of feedstock for biofuel production. Biodiesel, biogas, bioethanol, pharmaceuticals, nutraceuticals and other valuable products can be obtained from algae. Biofuels are renewable, biodegradable, and environmentally-friendly. Algae possess many desirable features such as rapid-growth and high lipid content. Chlorophytes (including micro- and macro-algae) represent the biggest group of algae with applications in bioremediation, water treatment, food supply, pharmaceuticals and energy production. In this work, we shed light on different cultivation, harvesting and processing methods. The key challenges appear to be the high infrastructure, operation, and maintenance costs, selection of high lipid containing algal strains, harvesting on a commercial scale and water evaporation issues. Innovative and efficient techniques are necessary to make algal biofuel production preferable. Enhanced biofuel production will help in natural resources conservation and in turn saving the environment.

Author Contributions: Conceptualization, writing—original draft preparation, M.G.S.; writing-draft preparation, review and editing, M.G.S. and N.S.D; writing-final draft review and editing, all authors. M.G.S. and N.S.D. contributed equally to this work.

Funding: This research received no external funding.

Acknowledgments: The authors are grateful to avid Nobles; Director of Curation of UTEX Culture Collection of Algae at University of Texas at Austin for providing original images of some presented algae. Also, authors would like to thank Nobles and Schonna Manning; Research Assistant Professor, Department of Molecular Biosciences at University of Texas at Austin for their valuable comments that enhancements that work.

Conflicts of Interest: The authors declare no conflict of interest.

\section{References}

1. Bhore, N. Energy Outlook: A View to 2040. Detroit Automotive Petroleum Forum: Detroit, MI, USA. Available online: https://www.api.org/ \{\}/media/files/certification/engine-oil-diesel/forms/whats-new/6energy-outlook-viewto2040-nbhore-exxonmobil.pdf (accessed on 17 May 2019).

2. Raheem, A.; Prinsen, P.; Vuppaladadiyam, A.K.; Zhao, M.; Luque, R. A review on sustainable microalgae based biofuel and bioenergy production: Recent developments. J. Clean. Prod. 2018, 181, 42-59. [CrossRef]

3. Judge, D.; Earnshaw, D. The European Parliament; Palgrave: Basingstoke, UK, 2003.

4. Office of Energy Efficiency \& Renewable Energy. Biofuels Basics. Available online: https://www.energy.gov/ eere/bioenergy/biofuels-basics (accessed on 17 May 2019).

5. European Biofuels Technology Platform. Strategic Research and Innovation Agenda 2016; European Biofuels Technology Platform: London, UK, 2016.

6. Lü, J.; Sheahan, C.; Fu, P. Metabolic engineering of algae for fourth generation biofuels production. Energy Environ. Sci. 2011, 4, 2451-2466. [CrossRef]

7. Rosenthal, E. UN report describes risks of inaction on climate change. The New York Times, 2007; 17.

8. Brown, T.R.; Brown, R.C. A review of cellulosic biofuel commercial-scale projects in the United States. Biofuels Bioprod. Biorefin. 2013, 7, 235-245. [CrossRef]

9. Nigam, G.; Singh, R.; Chaturvedi, A.K. Finite duration root nyquist pulses with maximum in-band fractional energy. IEEE Commun. Lett. 2010, 14, 797-799. [CrossRef]

10. Dutta, K.; Daverey, A.; Lin, J. Evolution retrospective for alternative fuels: First to fourth generation. Renew. Energy 2014, 69, 114-122. [CrossRef]

11. Sawin, J.L.; Martinot, E.; Sonntag-O’Brien, V.; McCrone, A.; Roussell, J.; Barnes, D.; Flavin, C.; Mastny, L.; Kraft, D.; Wang, S.; et al. Renewables 2010—Global Status Report; Deutsche Gesellschaft für Technische Zusammenarbeit (GTZ) GmbH: Paris, France, 2013. 
12. Shuba, E.S.; Kifle, D. Microalgae to biofuels: 'Promising' alternative and renewable energy, review. Renew. Sustain. Energy Rev. 2018, 81, 743-755. [CrossRef]

13. Beacham, T.A.; Sweet, J.B.; Allen, M.J. Large scale cultivation of genetically modified microalgae: A new era for environmental risk assessment. Algal Res. 2017, 25, 90-100. [CrossRef]

14. Levitan, O.; Dinamarca, J.; Hochman, G.; Falkowski, P.G. Diatoms: A fossil fuel of the future. Trends Biotechnol. 2014, 32, 117-124. [CrossRef]

15. Shafik, H.M.; Saad, M.G.; El-Serehy, H.A. Impact of nitrogen regime on fatty acid profiles of Desmodesmus quadricaudatus and Chlorella sp. and ability to produce biofuel. Acta Bot. Hung. 2015, 57, 205-218. [CrossRef]

16. Adeniyi, O.M.; Azimov, U.; Burluka, A. Algae biofuel: Current status and future applications. Renew. Sustain. Energy Rev. 2018, 90, 316-335. [CrossRef]

17. Tsukahara, K.; Sawayama, S. Liquid fuel production using microalgae. J. Jpn. Pet. Inst. 2005, 48, 251. [CrossRef]

18. Chisti, Y. Biodiesel from microalgae. Biotechnol. Adv. 2007, 25, 294-306. [CrossRef]

19. Rawat, I.; Kumar, R.R.; Mutanda, T.; Bux, F. Biodiesel from microalgae: A critical evaluation from laboratory to large scale production. Appl. Energy 2013, 103, 444-467. [CrossRef]

20. Lam, M.K.; Lee, K.T. Renewable and sustainable bioenergies production from palm oil mill effluent (POME): Win-win strategies toward better environmental protection. Biotechnol. Adv. 2011, 29, 124-141. [CrossRef]

21. Van Wagenen, J.; Miller, T.W.; Hobbs, S.; Hook, P.; Crowe, B.; Huesemann, M. Effects of light and temperature on fatty acid production in Nannochloropsis salina. Energies 2012, 5, 731-740. [CrossRef]

22. Zheng, Y.; Li, T.; Yu, X.; Bates, P.D.; Dong, T.; Chen, S. High-density fed-batch culture of a thermotolerant microalga Chlorella sorokiniana for biofuel production. Appl. Energy 2013, 108, 281-287. [CrossRef]

23. Hu, Q.; Sommerfeld, M.; Jarvis, E.; Ghirardi, M.; Posewitz, M.; Seibert, M.; Darzins, A. Microalgal triacylglycerols as feedstocks for biofuel production: Perspectives and advances. Plant J. 2008, 54, 621-639. [CrossRef] [PubMed]

24. Love, K.R.; Bagh, S.; Choi, J.; Love, J.C. Microtools for single-cell analysis in biopharmaceutical development and manufacturing. Trends Biotechnol. 2013, 31, 280-286. [CrossRef] [PubMed]

25. Zheng, G.; Wang, Y.; Qin, J. Microalgal motility measurement microfluidic chip for toxicity assessment of heavy metals. Anal. Bioanal. Chem. 2012, 404, 3061-3069. [CrossRef] [PubMed]

26. Hashemi, J.; Worrall, C.; Vasilcanu, D.; Fryknäs, M.; Sulaiman, L.; Karimi, M.; Weng, W.H.; Lui, W.O.; Rudduck, C.; Axelson, M.; et al. Molecular characterization of acquired tolerance of tumor cells to picropodophyllin (PPP). PLoS ONE 2011, 6, e14757. [CrossRef]

27. Lim, H.S.; Kim, J.Y.H.; Kwak, H.S.; Sim, S.J. Integrated microfluidic platform for multiple processes from microalgal culture to lipid extraction. Anal. Chem. 2014, 86, 8585-8592. [CrossRef] [PubMed]

28. Deng, Y.L.; Kuo, M.Y.; Juang, Y.J. Development of flow through dielectrophoresis microfluidic chips for biofuel production: Sorting and detection of microalgae with different lipid contents. Biomicrofluidics 2014, 8 , 064120. [CrossRef]

29. Wang, K.; Brown, R.C.; Homsy, S.; Martinez, L.; Sidhu, S.S. Fast pyrolysis of microalgae remnants in a fluidized bed reactor for bio-oil and biochar production. Bioresour. Technol. 2013, 127, 494-499. [CrossRef]

30. Abalde-Cela, S.; Gould, A.; Liu, X.; Kazamia, E.; Smith, A.G.; Abell, C. High-throughput detection of ethanol-producing cyanobacteria in a microdroplet platform. J. R. Soc. Interface 2015, 12, 20150216. [CrossRef]

31. Hammar, P.; Angermayr, S.A.; Sjostrom, S.L.; van der Meer, J.; Hellingwerf, K.J.; Hudson, E.P.; Joensson, H.N. Single-cell screening of photosynthetic growth and lactate production by cyanobacteria. Biotechnol. Biofuels 2015, 8, 193. [CrossRef]

32. Liao, Q.; Chang, J.S.; Herrmann, C.; Xia, A. Bioreactors for Microbial Biomass and Energy Conversion; Springer: Berlin/Heidelberg, Germany, 2018.

33. Lee, O.K.; Lee, E.Y. Sustainable production of bioethanol from renewable brown algae biomass September. Biomass Bioenergy 2016, 92, 70-75. [CrossRef]

34. Brennan, L.; Owende, P. Biofuels from microalgae-A review of technologies for production, processing, and extractions of biofuels and co-products. Renew. Sustain. Energy Rev. 2010, 14, 557-577. [CrossRef]

35. Huang, G.; Chen, F.; Wei, D.; Zhang, X.; Chen, G. Biodiesel production by microalgal biotechnology. Appl. Energy 2010, 87, 38-46. [CrossRef] 
36. Suganya, T.; Varman, M.; Masjuki, H.H.; Renganathan, S. Macroalgae and microalgae as a potential source for commercial applications along with biofuels production: A biorefinery approach. Renew. Sustain. Energy Rev. 2016, 55, 909-941. [CrossRef]

37. Leite, G.B.; Abdelaziz, A.E.M.; Hallenbeck, P.C. Bioresource technology algal biofuels: Challenges and opportunities. Bioresour. Technol. 2013, 145, 134-141. [CrossRef]

38. Mata, T.M.; Martins, A.A.; Caetano, N.S. Microalgae for biodiesel production and other applications: A review. Renew. Sustain. Energy Rev. 2010, 14, 217-232. [CrossRef]

39. Shaikh Abdur, R.; Saad Aldin, M.A.; Mohammad Mozahar, H.; Hugo, L. Biological $\mathrm{CO}_{2}$ fixation with production of microalgae in wastewater: A review. Renew. Sustain. Energy Rev. 2017, 76, 379-390.

40. Schenk, P.M.; Thomas-Hall, S.R.; Stephens, E.; Marx, U.C.; Mussgnug, J.H.; Posten, C. Second generation biofuels: High-effjciency microalgae for biodiesel production. Bioenergy Res. 2008, 1, 20-43. [CrossRef]

41. Daliry, S.; Hallajsani, A.; Mohammadi Roshandeh, J.; Nouri, H.; Golzary, A. Investigation of optimal condition for Chlorella vulgaris microalgae growth. Glob. J. Environ. Sci. Manag. 2017, 3, 217-230.

42. Chen, C.Y.; Durbin, E.G. Effects of $\mathrm{pH}$ on the growth and carbon uptake of marine phytoplankton. Mar. Ecol. Ser. 1994, 109, 83. [CrossRef]

43. Huppe, H.C.; Turpin, D.H. Integration of carbon and nitrogen metabolism in plant and algal cells. Annu. Rev. Plant Biol. 1994, 45, 577-607. [CrossRef]

44. Andrews, J.F. A mathematical model for the continuous culture of microorganisms utilizing inhibitory substrates. Biotechnol. Bioenergy 1968, 10, 707-723. [CrossRef]

45. Martinez, F.; Ascaso, C.; Orus, M.I. Morphometric and stereologic analysis of Chlorella vulgaris under heterotrophic growth conditions. Ann. Bot. 1991, 67, 239-245. [CrossRef]

46. Scarsella, M.; Belotti, G.; De Filippis, P.; Bravi, M. Study on the optimal growing conditions of Chlorella vulgaris in bubble column photobioreactors. Chem. Eng. 2010, 20, 85-90.

47. Butterfi, B.A.; Jones, J. Harvesting of algae grown in agricultural wastewaters. Trans. Geophys. Union. 1969, $50,612$.

48. Chen, C.-L.; Chang, J.-S.; Lee, D.-J. Dewatering and drying methods for Microalgae. Dry. Technol. 2015, 33, 443-454. [CrossRef]

49. Grima, E.M.; Belarbi, E.H.; Fernández, F.A.; Medina, A.R.; Chisti, Y. Recovery of microalgal biomass and metabolites: Process options and economics. Biotechnol. Adv. 2003, 20, 491-515. [CrossRef]

50. Lee, D.H.; Bae, C.Y.; Han, J.I.; Park, J.K. In situ analysis of heterogeneity in the lipid content of single green microalgae in alginate hydrogel microcapsules. Anal. Chem. 2013, 85, 8749-8756. [CrossRef]

51. Divakaran, R.; Pillai, V.N. Flocculation of river silt using chitosan. Water Res. 2002, 36, 2414-2418. [CrossRef]

52. Giovannoni, S.J.; DeLong, E.F.; Schmidt, T.M.; Pace, N.R. Tangential flow filtration and preliminary phylogenetic analysis of marine picoplankton. Appl. Environ. Microbiol. 1990, 56, 2572-2575. [PubMed]

53. Bosma, R.; van Spronsen, W.A.; Tramper, J.; Wijffels, R.H. Ultrasound, a new separation technique to harvest microalgae. J. Appl. Phycol. 2003, 15, 143-153. [CrossRef]

54. Gröschl, M. Ultrasonic Separation of Suspended Particles-Part I: Fundamentals. Acta Acust. United Acust. 1998, 84, 432-447.

55. Muñoz, R.; Guieysse, B. Algal-bacterial processes for the treatment of hazardous contaminants: A review. Water Res. 2006, 40, 2799-2815. [CrossRef]

56. Hossain, A.; Salleh, A.; Boyce, A.; Chowdhury, P.; Naqiuddin, M. Biodiesel fuel production from microalgae as renewable energy. Am. J. Biochem. Biotechnol. 2008, 4, 250-254.

57. Ward, A.J.; Lewis, D.M.; Green, F.B. Anaerobic digestion of algae biomass: A review. Algal Res. 2014, 5, 204-214. [CrossRef]

58. Oncel, S.S.; Kose, A.; Faraloni, C.; Imamoglu, E.; Elibol, M.; Torzillo, G.; Vardar Sukan, F. Biohydrogen production from model microalgae Chlamydomonas reinhardtii: A simulation of environmental conditions for outdoor experiments. Int. J. Hydrogen Energy 2015, 40, 7502-7510. [CrossRef]

59. RangaRao, A.; Ravishankar, G.A. Infmuence of $\mathrm{CO}_{2}$ on growth and hydrocarbon production in Botryococcus braunii. J. Microbiol. Biotechnol. 2007, 17, 414-419.

60. Buxy, S.; Diltz, R.; Pullammanappallil, P. Biogasification of Marine Algae Nannochloropsis Oculata; Wicks, G., Simon, J., Zidan, R., Brigmon, R., Fischman, G., Arepalli, S., Norris, A., McCluer, M., Eds.; John Wiley \& Sons, Inc.: Hoboken, NJ, USA, 2013. 
61. Ghasemi, Y.; Rasoul-Amini, S.; Naseri, A.T.; Montazeri-Najafabady, N.; Mobasher, M.A. Microalgae biofuel potentials. Appl. Biochem. Microbiol. 2012, 48, 126-144. [CrossRef]

62. Archana, T.; Anjana, P. Cyanobacterial hydrogen production: A step towards clean environment. Int. J. Hydrogen Energy 2012, 37, 139-150.

63. Markou, G.; Angelidaki, I.; Georgakakis, D. Microalgal carbohydrates: An overview of the factors influencing carbohydrates production, and of main bioconversion technologies for production of biofuels. Appl. Microbiol. Biotechnol. 2012, 96, 631-645. [CrossRef] [PubMed]

64. Chen, C.Y.; Zhao, X.Q.; Yen, H.W.; Ho, S.H.; Cheng, C.L.; Lee, D.J.; Bai, F.W.; Chang, J.S. Microalgae-based carbohydrates for biofuel production. Biochem. Eng. J. 2013, 78, 1-10. [CrossRef]

65. Harun, R.; Danquah, M.K.; Forde, G.M. Microalgal biomass as a fermentation feedstock for bioethanol production. J. Chem. Technol. Biotechnol. 2010, 85, 199-203. [CrossRef]

66. Hamelinck, C.N.; van Hooijdonk, G.; Faaij, A.P.C. Ethanol from lignocellulosic biomass: Techno-economic performance in short-, middle- and long-term. Biomass Bioenergy 2005, 28, 384-410. [CrossRef]

67. Ehimen, E.A.; Sun, Z.F.; Carrington, C.G. Variables affecting the in situ transesterification of microalgae lipids. Fuel 2010, 89, 677-684. [CrossRef]

68. Huang, J.; Xia, J.; Jiang, W.; Li, Y.; Li, J. Biodiesel production from microalgae oil catalyzed by a recombinant lipase. Bioresour. Technol. 2015, 180, 47-53. [CrossRef]

69. Tang, H.; Abunasser, N.; Garcia, M.E.D.; Chen, M.; Ng, K.Y.S.; Salley, S.O. Potential of microalgae oil from Dunaliella tertiolecta as a feedstock for biodiesel. Appl. Energy 2011, 88, 3324-3330. [CrossRef]

70. Carvalho Júnior, R.M.; Vargas, J.V.C.; Ramos, L.P.; Marino, C.E.B.; Torres, J.C.L. Microalgae biodiesel via in situ methanolysis. J. Chem. Technol. Biotechnol. 2011, 86, 1418-1427. [CrossRef]

71. El-Shimi, H.I.; Attia, N.K.; El-Sheltawy, S.T.; El-Diwani, G.I. Biodiesel production from spirulina-platensis microalgae by in-situ transesterification process. J. Sustain. Bioenergy Syst. 2013, 3, 224-233. [CrossRef]

72. Johnson, M.B.; Wen, Z. Production of biodiesel fuel from the Microalga Schizochytrium limacinum by direct transesterification of algal biomass. Energy Fuels 2009, 23, 5179-5183. [CrossRef]

73. Afify, A.E.-M.M.R.; Shalaby, E.A.; Shanab, S.M.M. Enhancement of biodiesel production from different species of algae. Grasas y Aceites 2010, 61, 416-422.

74. Saad, M.G.; Shafik, H.M.; Mekki, L.; El-Kholy, R. Impact of different nitrogen concentrations on biomass productivity, lipid content and target fatty acids within Chlorella sp. and Desmodesmus quadricaudatus to enhance biodiesel production. Int. J. Sci. Technol. Res. 2018, 7, 123-130.

75. Saad, M.G.; Shafik, H.M. The challenges of biodiesel production from Oscillatoria sp. J. Int. J. Adv. Res. 2017, 5, 1316-1322. [CrossRef]

76. Choi, S.P.; Nguyen, M.T.; Sim, S.J. Enzymatic pretreatment of Chlamydomonas reinhardtii biomass for ethanol production. Bioresour. Technol. 2010, 101, 5330-5336. [CrossRef]

77. Nayak, B.K.; Roy, S.; Das, D. Biohydrogen production from algal biomass (Anabaena sp. PCC 7120) cultivated in airlift photobioreactor. Int. J. Hydrogen Energy 2014, 39, 7553-7560. [CrossRef]

78. Miyamoto, K.; Hallenbeck, P.C.; Benemann, J.R. Hydrogen production by the thermophilic alga Mastigocladus laminosus: Hydrogen production by the thermophilic alga Mastigocladus laminosus: Effects of nitrogen, temperature, and inhibition of photosynthesis. Appl. Environ. Microbiol. 1979, 38, 440-446.

79. Barreiro, D.L.; Prins, W.; Ronsse, F.; Brilman, W. Hydrothermal liquefaction (HTL) of microalgae for biofuel production: State of the art review and future prospects. Biomass Bioenergy 2013, 53, 113-127. [CrossRef]

80. Biller, P.; Ross, A.B.; Skill, S.C.; Lea-Langton, A.; Balasundaram, B.; Hall, C.; Riley, R.; Llewellyn, C.A. Nutrient recycling of aqueous phase for microalgae cultivation from the hydrothermal liquefaction process. Algal Res. 2012, 1, 70-76. [CrossRef]

81. Biller, P.; Ross, A.B. Potential yields and properties of oil from the hydrothermal liquefaction of microalgae with different biochemical content. Bioresour. Technol. 2011, 102, 215-225. [CrossRef]

82. Eboibi, B.E.; Lewis, D.M.; Ashman, P.J.; Chinnasamy, S. Effect of operating conditions on yield and quality of biocrude during hydrothermal liquefaction of halophytic microalga Tetraselmis sp. Bioresour Technol. 2014, 170, 20-29. [CrossRef]

83. Huang, Y.; Chen, Y.; Xie, J.; Liu, H.; Yin, X.; Wu, C. Bio-oil production from hydrothermal liquefaction of high-protein high-ash microalgae including wild Cyanobacteria sp. and cultivated Bacillariophyta sp. Fuel 2016, 183, 9-19. [CrossRef] 
84. Alba, L.G.; Torri, C.; Samorì, C.; van der Spek, J.; Fabbri, D.; Kersten, S.R.A.; Brilman, D.W.F. (Wim) Hydrothermal treatment (HTT) of Microalgae: Evaluation of the process as conversion method in an algae biorefinery concept. Energy Fuels 2012, 26, 642-657. [CrossRef]

85. Hirano, A.; Ueda, R.; Hirayama, S.; Ogushi, Y. $\mathrm{CO}_{2}$ fixation and ethanol production with microalgal photosynthesis and intracellular anaerobic fermentation. Energy 1997, 22, 137-142. [CrossRef]

86. Wu, Q.; Shiraiwa, Y.; Takeda, H.; Sheng, G.; Fu, J. Liquid-saturated hydrocarbons resulting from pyrolysis of the marine coccolithophores Emiliania huxleyi and Gephyrocapsa oceanica. Mar. Biotechnol. 1999, 1, 346-352. [CrossRef] [PubMed]

87. Zamalloa, C.; Boon, N.; Verstraete, W. Anaerobic digestibility of Scenedesmus obliquus and Phaeodactylum tricornutum under mesophilic and thermophilic conditions. Appl. Energy 2012, 92, 733-738. [CrossRef]

88. Inglesby, A.E.; Fisher, A.C. Enhanced methane yields from anaerobic digestion of Arthrospira maxima biomass in an advanced flow-through reactor with an integrated recirculation loop microbial fuel cell. Energy Environ. Sci. 2012, 5, 7996-8006. [CrossRef]

89. Nguyen, T.; Roddick, F.A.; Fan, L. Impact of green algae on the measurement of Microcystis aeruginosa populations in lagoon-treated wastewater with an algae online analyser. Environ. Technol. 2015, 36, 556-565. [CrossRef] [PubMed]

90. Rizzo, A.M.; Prussi, M.; Bettucci, L.; Libelli, I.M.; Chiaramonti, D. Characterization of microalga Chlorella as a fuel and its thermogravimetric behavior. Appl. Energy 2013, 102, 24-31. [CrossRef]

91. Miao, X.; Wu, Q.; Yang, C. Fast pyrolysis of microalgae to produce renewable fuels. J. Anal. Appl. Pyrolysis 2004, 71, 855-863. [CrossRef]

92. Babich, I.V.; van der Hulst, M.; Lefferts, L.; Moulijn, J.A.; O'Connor, P.; Seshan, K. Catalytic pyrolysis of microalgae to high-quality liquidbio-fuels. Biomass Bioenergy 2011, 35, 3199-3207. [CrossRef]

93. Wang, Y.; Yang, Y.; Ma, F.; Xuan, L.; Xu, Y.; Huo, H.; Zhou, D.; Dong, S. Optimization of Chlorella vulgaris and bioflocculant-producing bacteria co-culture: Enhancing microalgae harvesting and lipid content. Lett. Appl. Microbiol. 2015, 60, 497-503. [CrossRef]

94. Grierson, S.; Strezov, V.; Ellem, G.; Mcgregor, R.; Herbertson, J. Thermal characterisation of microalgae under slow pyrolysis conditions. J. Anal. Appl. Pyrolysis 2009, 85, 118-123. [CrossRef]

95. Pan, P.; Hu, C.; Yang, W.; Li, Y.; Dong, L.; Zhu, L.; Tong, D.; Qing, R.; Fan, Y. The direct pyrolysis and catalytic pyrolysis of Nannochloropsis sp. residue for renewable bio-oils. Bioresour. Technol. 2010, 101, 4593-4599. [CrossRef] [PubMed]

96. Grierson, S.; Strezov, V.; Shah, P. Properties of oil and char derived from slow pyrolysis of Tetraselmis chui. Bioresour. Technol. 2011, 102, 8232-8240. [CrossRef]

97. Onwudili, J.A.; Lea-Langton, A.R.; Ross, A.B.; Williams, P.T. Catalytic hydrothermal gasification of algae for hydrogen production: Composition of reaction products and potential for nutrient recycling. Bioresour. Technol. 2013, 127, 72-80. [CrossRef]

98. Khoo, H.H.; Koh, C.Y.; Shaik, M.S.; Sharratt, P.N. Bioenergy co-products derived from microalgae biomass via thermochemical conversion-Life cycle energy balances and $\mathrm{CO}_{2}$ emissions. Bioresour. Technol. 2013, 143, 298-307. [CrossRef] [PubMed]

99. Duman, G.; Uddin, M.A.; Yanik, J. Hydrogen production from algal biomass via steam gasification. Bioresour. Technol. 2014, 166, 24-30. [CrossRef]

100. Sanchez-Silva, L.; López-González, D.; Garcia-Minguillan, A.M.; Valverde, J.L. Pyrolysis, combustion and gasification characteristics of Nannochloropsis gaditana microalgae. Bioresour. Technol. 2013, 130, 321-323. [CrossRef] [PubMed]

101. Stucki, S.; Vogel, F.; Ludwig, C.; Haiduc, A.G.; Brandenberger, M. Catalytic gasification of algae in supercritical water for biofuel production and carbon capture. Energy Environ. Sci. 2009, 2, 535-541. [CrossRef]

102. Alghurabie, I.K.; Hasan, B.O.; Jackson, B.; Kosminski, A.; Ashman, P.J. Fluidized bed gasification of Kingston coal and marine microalgae in a spouted bed reactor. Chem. Eng. Res. Des. 2013, 91, 1614-1624. [CrossRef]

103. Woertz, I.C.; Benemann, J.R.; Du, N.; Unnasch, S.; Mendola, D.; Mitchell, B.G.; Lundquist, T.J. Life cycle GHG emissions from microalgal biodiesel-a CA-GREET model. Environ. Sci. Technol. 2014, 48, 6060-6068. [CrossRef]

104. Langholtz, M.H.; Stokes, B.J.; Eaton, L.M. U.S. Department of Energy, Billion-Ton Report: Advancing Domestic Resources for a Thriving Bioeconomy, Volume 1: Economic Availability of Feedstocks (Leads); Oak Ridge National Laboratory: Oak Ridge, TN, USA, 2016. 
105. Raheem, A.; Azlina, W.W.; Yap, Y.T.; Danquah, M.K.; Harun, R. Thermochemical conversion of microalgal biomass for biofuel production. Renew. Sustain. Energy Rev. 2015, 49, 990-999. [CrossRef]

106. Naik, S.N.; Goud, V.V.; Rout, P.K.; Dalai, A.K. Production of first and second generation biofuels: A comprehensive review. Renew. Sustain. Energy Rev. 2010, 14, 578-597. [CrossRef]

107. Chaiwong, K.; Kiatsiriroat, T.; Vorayos, N.; Thararax, C. Study of bio-oil and bio-char production from algae by slow pyrolysis. Biomass Bioenergy 2013, 56, 600-606. [CrossRef]

108. Campanella, A.; Muncrief, R.; Harold, M.P.; Griffith, D.C.; Whitton, N.M.; Weber, R.S. Thermolysis of microalgae and duckweed in a $\mathrm{CO}_{2}$-swept fixed-bed reactor: Bio-oil yield and compositional effects. Bioresour. Technol. 2012, 109, 154-162. [CrossRef] [PubMed]

109. Zhang, Y.; Chen, P.; Liu, S.; Fan, L.; Zhou, N.; Min, M.; Cheng, Y.; Peng, P.; Anderson, E.; Wang, Y.; et al. Microwave-assisted pyrolysis of biomass for bio-oil production. In Pyrolysis; IntechOpen: London, UK, 2017; pp. 129-166.

110. Brand, S.; Hardi, F.; Kim, J.; Suh, D.J. Effect of heating rate on biomass liquefaction: Differences between subcritical water and supercritical ethanol. Energy 2014, 68, 420-427. [CrossRef]

111. Chen, W.H.; Lin, B.J.; Huang, M.Y.; Chang, J.S. Thermochemical conversion of microalgal biomass into biofuels: A review. Bioresour. Technol. 2015, 184, 314-327. [CrossRef]

112. Shuping, Z.; Yulong, W.; Mingde, Y.; Kaleem, I.; Chun, L.; Tong, J. Production and characterization of bio-oil from hydrothermal liquefaction of microalgae Dunaliella tertiolecta cake. Energy 2010, 35, 5406-5411. [CrossRef]

113. Ross, A.B.; Biller, P.; Kubacki, M.L.; Li, H.; Lea-Langton, A.; Jones, J.M. Hydrothermal processing of microalgae using alkali and organic acids. Fuel 2010, 89, 2234-2243. [CrossRef]

114. Chiaramonti, D.; Prussi, M.; Buffi, M.; Rizzo, A.M.; Pari, L. Review and experimental study on pyrolysis and hydrothermal liquefaction of microalgae for biofuel production. Appl. Energy 2017, 185, 963-972. [CrossRef]

115. Raza, H. Aspen Simulation of Hydrothermal Liquefaction Process for the Conversion of Algae to Renewable Fuels and Chemicals; Lamar University-Beaumont: Beaumont, TX, USA, 2014.

116. Dote, Y.; Sawayama, S.; Inoue, S.; Minowa, T.; Yokoyama, S.Y. Recovery of liquid fuel from hydrocarbon-rich microalgae by thermochemical liquefaction. Fuel 1994, 73, 1855-1857. [CrossRef]

117. Zou, S.; Wu, Y.; Yang, M.; Li, C.; Tong, J. Bio-oil production from sub-and supercritical water liquefaction of microalgae Dunaliella tertiolecta and related properties. Energy Environ. Sci. 2010, 3, 1073-1078. [CrossRef]

118. Duan, P.; Savage, P.E. Hydrothermal liquefaction of a microalga with heterogeneous catalysts. Ind. Eng. Chem. Res. 2010, 50, 52-61. [CrossRef]

119. Ramos-Suárez, J.L.; Carreras, N. Use of microalgae residues for biogas production. Chem. Eng. J. 2014, 242, 86-95. [CrossRef]

120. Hidaka, T.; Inoue, K.; Suzuki, Y.; Tsumori, J. Growth and anaerobic digestion characteristics of microalgae cultivated using various types of sewage. Bioresour. Technol. 2014, 170, 83-89. [CrossRef]

121. Costa, J.C.; Gonçalves, P.R.; Nobre, A.; Alves, M.M. Biomethanation potential of macroalgae Ulva spp. and Gracilaria spp. and in co-digestion with waste activated sludge. Bioresour. Technol. 2012, 114, 320-326. [CrossRef]

122. Passos, F.; Solé, M.; García, J.; Ferrer, I. Biogas production from microalgae grown in wastewater: Effect of microwave pretreatment. Appl. Energy 2013, 108, 168-175. [CrossRef]

123. Marsolek, M.D.; Kendall, E.; Thompson, P.L.; Shuman, T.R. Thermal pretreatment of algae for anaerobic digestion. Bioresour. Technol. 2014, 151, 373-377. [CrossRef] [PubMed]

124. Laurens, L.M.L.; Nagle, N.; Davis, R.; Sweeney, N.; Van Wychen, S.; Lowell, A.; Pienkos, P.T. Acid-catalyzed algal biomass pretreatment for integrated lipid and carbohydrate-based biofuels production. Green Chem. 2015, 17, 1145-1158. [CrossRef]

125. Aikawa, S.; Joseph, A.; Yamada, R.; Izumi, Y.; Yamagishi, T.; Matsuda, F.; Kawai, H.; Chang, J.S.; Hasunuma, T.; Kondo, A. Direct conversion of Spirulina to ethanol without pretreatment or enzymatic hydrolysis processes. Energy Environ. Sci. 2013, 6, 1844-1849. [CrossRef]

126. Slade, R.; Bauen, A. Micro-algae cultivation for biofuels: Cost, energy balance, environmental impacts and future prospects. Biomass Bioenergy 2013, 53, 29-38. [CrossRef]

127. Fasahati, P.; Woo, H.C.; Liu, J. Industrial-scale bioethanol production from brown algae: Effects of pretreatment processes on plant economics. Appl. Energy 2015, 1139, 175-187. [CrossRef] 
128. Teixeira, A.C.R.; Sodré, J.R.; Guarieiro, L.L.N.; Vieira, E.D.; de Medeiros, F.F.; Alves, C.T. A Review on Second and Third Generation Bioethanol Production; SAE International: Warrendale, PA, USA, 2016; pp. 1-7.

129. Fan, X.; Wang, H.; Guo, R.; Yang, D.; Zhang, Y.; Yuan, X.; Qiu, Y.; Yang, Z.; Zhao, X. Comparative study of the oxygen tolerance of Chlorella pyrenoidosa and Chlamydomonas reinhardtii CC124 in photobiological hydrogen production. Algal Res. 2016, 16, 240-244. [CrossRef]

130. Antal, T.K.; Krendeleva, T.E.; Tyystjärvi, E. Multiple regulatory mechanisms in the chloroplast of green algae: Relation to hydrogen production. Photosynth. Res. 2015, 125, 357-381. [CrossRef]

131. Das, A.A.; Esfahani, M.M.; Velev, O.D.; Pamme, N.; Paunov, V.N. Artificial leaf device for hydrogen generation from immobilised C. reinhardtii microalgae. J. Mater. Chem. A 2015, 3, 20698-20707. [CrossRef]

132. Machado, I.M.; Atsumi, S. Cyanobacterial biofuel production. J. Biotechnol. 2012, 162, 50-56. [CrossRef]

133. Wahlen, B.D.; Willis, R.M.; Seefeldt, L.C. Biodiesel production by simultaneous extraction and conversion of total lipids from microalgae, cyanobacteria, and wild mixed-cultures. Bioresour. Technol. 2011, 102, 2724-2730. [CrossRef] [PubMed]

134. Patil, P.D.; Gude, V.G.; Mannarswamy, A.; Deng, S.; Cooke, P.; Munson-McGee, S.; Rhodes, I.; Lammers, P.; Nirmalakhandan, N. Optimization of direct conversion of wet algae to biodiesel under supercritical methanol conditions. Bioresour. Technol. 2011, 102, 118-122. [CrossRef]

135. Lee, J.H.; Kim, S.B.; Kang, S.W.; Song, Y.S.; Park, C.; Han, S.O.; Kim, S.W. Biodiesel production by a mixture of Candida rugosa and Rhizopus oryzae lipases using a supercritical carbon dioxide process. Bioresour. Technol. 2011, 102, 2105-2108. [CrossRef] [PubMed]

136. Knothe, G. Fuel properties of highly polyunsaturated fatty acid methyl esters. Prediction of fuel properties of algal biodiesel. Energy Fuel 2012, 26, 5265-5273. [CrossRef]

137. James, G.O.; Hocart, C.H.; Hillier, W.; Price, G.D.; Djordjevic, M.A. Temperature modulation of fatty acid profiles for biofuel production in nitrogen deprived Chlamydomonas reinhardtii. Bioresour. Technol. 2013, 127, 441-447. [CrossRef]

138. Dunn, R.O.; Bagby, M.O. Low-temperature properties of triglyceride-based diesel fuels: Transesterified methyl esters and petroleum middle distillate/Ester Blends. JAOCS 1995, 72, 895-904. [CrossRef]

139. Antczak, M.S.; Kubiak, A.; Antczak, T.; Bielecki, S. Enzymatic biodiesel synthesis-key factors affecting efficiency of the process. Renew. Energy 2009, 34, 1185-1194. [CrossRef]

140. Khan, S.A.; Hussain, M.Z.; Prasad, S.; Banerjee, U.C. Prospects of biodiesel production from microalgae in India. Renew. Sustain. Energy Rev. 2009, 13, 2361-2372. [CrossRef]

141. Bajhaiya, A.K.; Mandotra, S.K.; Suseela, M.R.; Toppo, K.; Ranade, S. ALGAL BIODIESEL: The next generation biofuel for India. Asian J. Exp. Biol. Sci 2010, 1, 728-739.

142. Mohan, S.V.; Srikanth, S.; Chiranjeevi, P.; Arora, S.; Chandra, R. Algal biocathode for in situ terminal electron acceptor (TEA) production: Synergetic association of bacteria-Microalgae metabolism for the functioning of biofuel cell. Bioresour. Technol. 2014, 166, 566-574. [CrossRef]

143. Angenent, L.T.; Karim, K.; Al-Dahhan, M.H.; Wrenn, B.A.; Domiguez-Espinosa, R. Production of bioenergy and biochemicals from industrial and agricultural wastewater. Trends Biotechnol. 2004, 22, 477-485. [CrossRef]

144. Saba, B.; Christy, A.D.; Yu, Z.; Co, A.C. Sustainable power generation from bacterio-algal microbial fuel cells (MFCs): An overview. Renew. Sustain. Energy Rev. 2017, 73, 75-84. [CrossRef]

145. Cucu, A.; Costache, T.A.; Tiliakos, A. Microalgae as native oxygen suppliers in bicameral microbial fuel cells. Dig. J. Nanomater. Biostruct. 2013, 8, 1301-1312.

146. Powell, E.E.; Evitts, R.W.; Hill, G.A. A microbial fuel cell with a photosynthetic microalgae cathodic half cell coupled to a yeast anodic half cell. Energy Sources Part A 2011, 33, 440-448. [CrossRef]

147. Commault, A.S.; Lear, G.; Novis, P. Photosynthetic biocathode enhances the power output of a sediment-type microbial fuel cell. N. Z. J. Bot. 2014, 52, 48-59. [CrossRef]

148. Wang, X.; Feng, Y.; Liu, J.; Lee, H.; Li, C.; Li, N.; Ren, N. Sequestration of $\mathrm{CO}_{2}$ discharged from anode by algal cathode in microbial carbon capture cells (MCCs). Biosens. Bioelectron. 2010, 25, 2639-2643. [CrossRef]

149. Juang, D.F.; Lee, C.H.; Hsueh, S.C.; Chou, H.Y. Power generation capabilities of microbial fuel cells with different oxygen supplies in the cathodic chamber. Appl. Biochem. Biotechnol. 2012, 167, 714-731. [CrossRef]

150. Wu, X.Y.; Song, T.S.; Zhu, X.J.; Wei, P.; Zhou, C. Construction and operation of microbial fuel cell with Chlorella vulgaris biocathode for electricity generation. Appl. Biochem. Biotechnol. 2013, 171, 2082-2092. [CrossRef]

151. Dunahay, T.G.; Jarvis, E.E.; Dais, S.S.; Roessler, P.G. Manipulation of microalgal lipid production using genetic engineering. Appl. Biochem. Biotechnol. 1996, 57, 223-231. [CrossRef] 
152. Courchesne, N.M.; Parisien, A.; Wang, B.; Lan, C.Q. Enhancement of lipid production using biochemical, genetic and transcription factor engineering approaches. J. Biotechnol. 2009, 141, 31-41. [CrossRef]

153. Siloto, R.M.P.; Truksa, M.; Brownfield, D.; Good, A.G.; Weselake, R.J. Directed evolution of acyl-CoA: Diacylglycerol acyltransferase: Development and characterization of Brassica napus DGAT1 mutagenized libraries. Plant Physiol. Biochem. 2009, 47, 456-461. [CrossRef]

154. Posewitz, M.C.; King, P.W.; Smolinski, S.L.; Smith, R.D.; Ginley, A.R.; Ghirardi, M.L.; Seibert, M. Identification of genes required for hydrogenase activity in Chlamydomonas reinhardtii. Biochem. Soc. Trans. 2005, 33, 102-103. [CrossRef] [PubMed]

155. Posewitz, M.C.; Smolinski, S.L.; Kanakagiri, S.; Melis, A.; Seibert, M.; Ghirardi, M.L. Hydrogen photoproduction is attenuated by disruption of an isoamylase gene in Chlamydomonas reinhardtii. Plant Cell 2004, 16, 2151-2163. [CrossRef] [PubMed]

156. Ramazanov, A.; Ramazanov, Z. Isolation and characterization of a starchless mutant of Chlorella pyrenoidosa STL-PI with a high growth rate, and high protein and polyunsaturated fatty acid content. Phycol. Res. 2006, 54, 255-259. [CrossRef]

157. Beer, L.L.; Boyd, E.S.; Peters, J.W.; Posewitz, M.C. Engineering algae for biohydrogen and biofuel production. Curr. Opin. Biotechnol. 2009, 20, 264-271. [CrossRef] [PubMed]

158. Melis, A.; Seibert, M.; Ghirardi, M.L. Hydrogen fuel production by transgenic microalgae. Adv. Exp. Med. Biol. 2007, 616, 110. [PubMed]

159. Kruse, O.; Rupprecht, J.; Bader, K.P.; Thomas-Hall, S.; Schenk, P.M.; Finazzi, G.; Hankamer, B. Improved photobiological $\mathrm{H} 2$ production in engineered green algal cells. J. Biol. Chem. 2005, 280, 34170-34177. [CrossRef] [PubMed]

160. Surzycki, R.; Cournac, L.; Peltier, G.; Rochaix, J.D. Potential for hydrogen production with inducible chloroplast gene expression in Chlamydomonas. Proc. Natl. Acad. Sci. USA 2007, 104, 17548-17553. [CrossRef] [PubMed]

161. Mussgnug, J.H.; Thomas-Hall, S.; Rupprecht, J.; Foo, A.; Klassen, V.; McDowall, A.; Schenk, P.M.; Kruse, O.; Hankamer, B. Engineering photosynthetic light capture: Impacts on improved solar energy to biomass conversion. Plant Biotechnol. J. 2007, 5, 802-814. [CrossRef]

162. Rasala, B.A.; Gimpel, J.A.; Tran, M.; Hannon, M.J.; Miyake-stoner, S.J.; Specht, E.A.; Mayfield, S.P. Genetic engineering to improve algal biofuels production. In Algae for Biofuels and Energy; Springer: Dordrecht, The Netherlands, 2013; pp. 99-113. ISBN 9789400754799.

163. Chen, G.Q.; Chen, F. Growing phototrophic cells without light. Biotech. Lett. 2006, 28, 607. [CrossRef]

164. Fischer, H.; Robl, I.; Sumper, M.; Kröger, N. Targeting and covalent modification of cell wall and membrane proteins heterologously expressed in the diatom Cylindrotheca fusiformis (Bacillariophyceae). J. Phycol. 1999, 35, 113-120. [CrossRef]

165. Hallmann, A.; Sumper, M. The Chlorella hexose/H + symporter is a useful selectable marker and biochemical reagent when expressed in Volvox. Proc. Natl. Acad. Sci. USA 1996, 93, 669-673. [CrossRef]

166. Doebbe, A.; Rupprecht, J.; Beckmann, J.; Mussgnug, J.H.; Hallmann, A.; Hankamer, B.; Kruse, O. Functional integration of the HUP1 hexose symporter gene into the genome of $C$. reinhardtii: Impacts on biological $\mathrm{H} 2$ production. J. Biotechnol. 2007, 131, 27-33. [CrossRef]

167. Zaslavskaia, L.A.; Lippmeier, J.C.; Shih, C.; Ehrhardt, D.; Grossman, A.R.; Apt, K.E. Trophic conversion of an obligate photoautotrophic organism through metabolic engineering. Science 2001, 292, 2073-2075. [CrossRef]

168. Radakovits, R.; Jinkerson, R.E.; Darzins, A.; Posewitz, M.C. Genetic engineering of algae for enhanced biofuel production. Eukaryot. Cell 2010, 9, 486-501. [CrossRef] [PubMed]

169. Wilson, W.; Brand, J. Principles of bioprospecting for microalgae. In Proceedings of the Algae Biomass Summit, Orlando, FL, USA, 30 September-3 October 2013.

170. Saladini, F.; Patrizi, N.; Pulselli, F.M.; Marchettini, N.; Bastianoni, S. Guidelines for emergy evaluation of first, second and third generation biofuels. Renew. Sustain. Energy Rev. 2016, 66, 221-227. [CrossRef]

171. Tomei, J.; Helliwell, R. Food versus fuel? Going beyond biofuels. Land Use Policy 2016, 56, 320-326. [CrossRef]

172. Wise, T.A.; Cole, E. Mandating Food Insecurity: The Global Impacts of Rising Biofuel Mandates and Targets; Global Development and Environment Institute: Medford, MA, USA, 2015.

173. Office of Energy Efficiency and Renewable Energy. National Algal Biofuels Technology Roadmap; U.S. Department of Energy: Washington, DC, USA, 2010. 
174. Cabanelas, I.T.D.; Ruiz, J.; Arbib, Z.; Chinalia, F.A.; Garrido-Pérez, C.; Rogalla, F.; Nascimento, I.A.; Perales, J.A. Comparing the use of different domestic wastewaters for coupling microalgal production and nutrient removal. Bioresour. Technol. 2013, 131, 429-436. [CrossRef] [PubMed]

175. Pimentel, D.; Patzek, T.W. Ethanol production using corn, switchgrass, and wood; Biodiesel production using soybean and sunflower. Nat. Resour. Res. 2005, 14, 65-76. [CrossRef]

176. Mutanda, T.; Ramesh, D.; Karthikeyan, S.; Kumari, S.; Anandraj, A.; Bux, F. Bioprospecting for hyper-lipid producing microalgal strains for sustainable biofuel production. Bioresour. Technol. 2011, 102, 57-70. [CrossRef]

177. Savage, P. Algae under pressure and in hot water. Science 2012, 338, 1039. [CrossRef]

178. Hall, C.A.S.; Dale, B.E.; Pimentel, D. Seeking to understand the reasons for different energy return on investment (EROI) estimates for biofuels. Sustainability 2011, 3, 2413-2432. [CrossRef]

179. Sills, D.L.; Paramita, V.; Franke, M.J.; Johnson, M.C.; Akabas, T.M.; Greene, C.H.; Tester, J.W. Quantitative uncertainty analysis of life cycle assessment for algal biofuel production. Environ. Sci. Technol. 2012, 47, 687-694. [CrossRef]

180. Youngs, H.; Somerville, C.R. California's Energy Future. The Potential for Biofuels; California Council on Science and Technology: Sacramento, CA, USA, 2013.

181. Gonzalez, L.M.; Kinnin, L.A.; Blikslager, A.T. Characterization of discrete equine intestinal epithelial cell lineages. Am. J. Vet. Res. 2015, 76, 358-366. [CrossRef]

182. Ruiz, J.; Olivieri, G.; de Vree, J.; Bosma, R.; Willems, P.; Reith, J.H.; Eppink, M.H.; Kleinegris, D.M.; Wijffels, R.H.; Barbosa, M.J. Towards industrial products from microalgae. Energy Environ. Sci. 2016, 9, 3036-3043. [CrossRef]

183. Rizwan, M.; Lee, J.H.; Gani, R. Optimal design of microalgae-based biorefinery: Economics, opportunities and challenges. Appl. Energy 2015, 150, 69-79. [CrossRef]

184. Vanthoor-koopmans, M.; Wijffels, R.H.; Barbosa, M.J.; Eppink, M.H.M. Biorefinery of microalgae for food and fuel. Bioresour. Technol. 2013, 135, 142-149. [CrossRef]

185. Pradhan, R.R.; Pradhan, R.R.; Das, S.; Dubey, B.; Dutta, A. Bioenergy combined with carbon capture potential by microalgae at flue gas-based carbon sequestration plant of NALCO as accelerated carbon sink. In Carbon Utilization; Springer: Singapore, 2017; pp. 231-244.

186. Li, Y.Q.; Horsman, M.; Wang, B.; Wu, N.; Lan, C.Q. Effects of nitrogen sources on cell growth and lipid accumulation of green alga Neochloris oleoabundans. Appl. Microbiol. Biotechnol. 2008, 81, 629-636. [CrossRef] [PubMed]

187. Langley, N.M.; Harrison, S.T.L.; Van Hille, R.P. A critical evaluation of $\mathrm{CO}_{2}$ supplementation to algal systems by direct injection. Biochem. Eng. J. 2012, 68, 70-75. [CrossRef] 